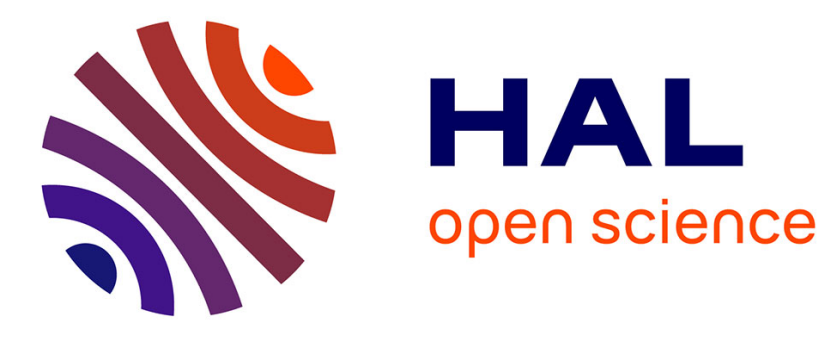

\title{
The CD95/CD95L signaling pathway: A role in carcinogenesis.
}

\author{
Amélie Fouqué, Laure Debure, Patrick Legembre
}

\section{To cite this version:}

Amélie Fouqué, Laure Debure, Patrick Legembre. The CD95/CD95L signaling pathway: A role in carcinogenesis.. BBA - Biochimica et Biophysica Acta, 2014, 1846 (1), pp.130-141. 10.1016/j.bbcan.2014.04.007 . hal-01061290

\section{HAL Id: hal-01061290 https://hal-univ-rennes1.archives-ouvertes.fr/hal-01061290}

Submitted on 5 Sep 2014

HAL is a multi-disciplinary open access archive for the deposit and dissemination of scientific research documents, whether they are published or not. The documents may come from teaching and research institutions in France or abroad, or from public or private research centers.
L'archive ouverte pluridisciplinaire HAL, est destinée au dépôt et à la diffusion de documents scientifiques de niveau recherche, publiés ou non, émanant des établissements d'enseignement et de recherche français ou étrangers, des laboratoires publics ou privés. 


\section{The CD95/CD95L Signaling Pathway: A Role in Carcinogenesis}

Amélie Fouqué $e^{1,2,3}$, Laure Debure ${ }^{1,2,3}$, and Patrick Legembre ${ }^{1,2,3,4}$

${ }^{1}$ Université Rennes-1, 2 Avenue du Professeur Léon Bernard, 35043, Rennes, France

${ }^{2}$ INSERM U1085, IRSET, 2 Avenue du Professeur Léon Bernard, 35043, Rennes, France

${ }^{3}$ Equipe Labellisée Ligue Contre Le Cancer "Death Receptors and Tumor Escape", 2 Avenue du Professeur Léon Bernard, 35043, Rennes, France

${ }^{4}$ Corresponding author: Université de Rennes-1, Faculté de Pharmacie, 2 avenue du Professeur Léon Bernard, 35043 Rennes, France. Phone: (+33)-22323-7241; email address: patrick.legembre@inserm.fr 


\begin{abstract}
Apoptosis is a fundamental process that contributes to tissue homeostasis, immune responses, and development. The receptor CD95, also called Fas, is a member of the tumor necrosis factor receptor (TNF-R) superfamily. Its cognate ligand, CD95L, is implicated in immune homeostasis and immune surveillance, and various lineages of malignant cells exhibit loss-offunction mutations in this pathway; therefore, CD95 was initially classified as a tumor suppressor gene. However, more recent data indicate that in different pathophysiological contexts, this receptor can transmit non-apoptotic signals, promote inflammation, and contribute to carcinogenesis. A comparison with the initial molecular events of the TNF-R signaling pathway leading to non-apoptotic, apoptotic, and necrotic pathways reveals that CD95 is probably using different molecular mechanisms to transmit its non-apoptotic signals (NF- $\mathrm{BB}, \mathrm{MAPK}$, and PI3K). As discussed in this review, the molecular process by which the receptor switches from an apoptotic function to an inflammatory role is unknown. More importantly, the biological functions of these signals remain elusive.
\end{abstract}

Keywords: Fas, apoptosis, cytokine, inflammation, carcinogenesis. 


\section{Introduction}

The two main apoptotic signaling pathways are distinguished by the origins of the initiating signals. The intrinsic pathway is triggered by accumulation of DNA damage, deregulation of mitochondrial function, or viral infection, and induces the release of pro-apoptotic factors from the mitochondria. By contrast, the extrinsic pathway is activated by the binding of apoptotic ligands to death receptors on the cell surface. The pathways are interconnected, and both converge on activation of a family of cysteine proteases specific for aspartic acid residues, the caspases [1]. The apoptotic role of the mitochondrion is associated with a reduction in transmembrane potential and the loss of extracellular membrane integrity, leading to the release of various apoptogenic factors into the cytosol. One of these factors, cytochrome $c$, associates with the caspase-9/APAF1 complex to form the apoptosome and trigger apoptosis [2].

The intrinsic and extrinsic pathways share common features, and both require the aggregation of initiator caspases as an early event. During interactions with their respective ligands, members of the death-receptor superfamily recruit adaptor proteins such as Fasassociating protein with a death domain (FADD) $[3,4]$ or Tumor Necrosis Factor (TNF) Receptor 1-Associated Death Domain Protein (TRADD) [5], resulting in the aggregation and activation of initiator caspases (caspase-8 and -10) to form the death-inducing signaling complex (DISC) [6]. In a similar manner, release of cytochrome $c$ and ATP from mitochondria promotes the formation of the apoptosome (along with cytosolic APAF-1), resulting in aggregation and activation of initiator caspase-9, which in turn cleaves caspase-3 $[7]$. 
It should be kept in mind that death receptors CD95 [8], TNFR1 [9], DR4 [10], DR5 [11], and DR6 [12] were cloned based on their ability to elicit apoptosis. Although the abilities of Fas/CD95, DR4, and DR5 to trigger non-apoptotic signaling pathways were observed immediately after the corresponding genes were cloned [13, 14], most if not all studies of these proteins have been focused on characterizing the molecular events leading to cell death. Accordingly, several agonistic molecules were developed in order to kill cancer cells, neglecting the impact of non-apoptotic signals in pathophysiological contexts. More recent data has altered this vision by highlighting the biological role of death receptormediated non-apoptotic signaling pathways in chronic inflammatory disorders and carcinogenesis.

\section{TNF Receptor Family}

Death receptors TNFR1, CD95, DR3, DR4, DR5, and DR6 belong to the tumor necrosis factor receptor (TNF-R) superfamily. These type I transmembrane proteins share common features: extracellular amino-terminal cysteine-rich domains (CRDs) [15, 16], which contribute to ligand specificity [17]; pre-association of the receptor at the plasma membrane [18-20]; and the death domain (DD), a conserved 80 amino-acid sequence located in the cytoplasmic tail, which is necessary for DISC formation and initiation of the apoptotic signal $[21,22]$.

\subsection{TNFR1 signaling pathways}

TNF- $\alpha$ exerts its effects by binding to two receptors, TNFR1 and TNFR2 [16]. Recently, progranulin was identified as a ligand of TNFR with a higher affinity than TNF- $\alpha$. Progranulin antagonizes TNF- $\alpha$ signaling and plays a critical role in the pathogenesis of inflammatory arthritis in mice [23]. TNFR1, a $55 \mathrm{kDa}$ protein with a DD in its intracellular 
region, is expressed in almost all cell types, whereas, TNFR2, a $75 \mathrm{kDa}$ protein, is mainly expressed in oligodendrocytes, astrocytes, $\mathrm{T}$ cells, myocytes, thymocytes, endothelial cells, and human mesenchymal stem cells [24]. Considerable uncertainty persists regarding the TNFR2 signaling pathway, which has been reviewed previously [24]. The CRD1 domains of CD95, TNFR1, and TNFR2 are involved in homotypic interactions, leading to pre-association of the receptor as a homotrimer in the absence of ligand [19, 20, 25]. Thus, this domain has been designated the pre-ligand binding assembly domain (PLAD) [25]. Receptors of the TNFR superfamily do not possess any enzymatic activity on their own, and therefore rely on the recruitment of adaptor proteins for signaling. Among these adaptor proteins, TRADD or FADD are instrumental in the implementation of cell death processes [3-6].

TNF- $\alpha$ is synthesized as a $26 \mathrm{kDa}$ transmembrane type II protein (m-TNF- $\alpha$ ) of 233 amino acids [26], which can be cleaved by the metalloprotease TACE [27, 28] to release the $17 \mathrm{kDa}$ soluble form of the cytokine (cl-TNF- $\alpha$ ). In contrast to cl-TNF- $\alpha$, which only activates TNFR1, m-TNF- $\alpha$ can bind and activate both TNFR1 and TNFR2 [29].

Activation of TNFR1 induces cellular processes ranging from cell death (apoptosis or necroptosis) to cell proliferation, migration, and differentiation; the implementation of these cellular responses reflects the formation of different molecular complexes following receptor activation [24]. Binding of TNF to TNFR1 causes formation of two consecutive complexes, resulting in the divergence of their kinetic and spatial distributions. Whereas the plasma membrane complex (complex I) elicits a non-apoptotic signaling pathway, a second, internalized complex (complex II or DISC) triggers cell death [30]. In the presence of TNF- $\alpha$, the adaptor protein TRADD interacts with TNFR1 and recruits other proteins involved in the signaling of the receptor, such as TRAF2, cIAP1, cIAP2, and RIP1, to form complex I. At the plasma membrane, this complex activates the NF- $\kappa \mathrm{B}$ signaling pathway, which in turn promotes transcription of anti-apoptotic genes such as cIAP-1, cIAP-2, and c-FLIP [31]. The 
linear ubiquitin chain assembly complex (LUBAC) is also recruited to complex I via cIAPgenerated ubiquitin chains [32]. The LUBAC complex consists of HOIL-1, HOIP, and sharpin; HOIL-1 and HOIP add a linear ubiquitin chain by catalyzing the head-to-tail ligation of ubiquitin [33] to RIP1 and NEMO (IKK $\gamma$ ) in complex I [34], thereby activating NF- $\kappa B$.

TNF- $\alpha$-induced caspase activation is mediated by a second intracellular complex, known as complex II, which is formed when complex I dissociates from the receptor along with FADD and caspase- 8 recruitment [30]. NF- $\kappa$ B activation leads to c-FLIP overexpression, preventing formation of complex II. Contrariwise, when NF- $\kappa \mathrm{B}$ activation is blocked, the short-lived cFLIP protein is depleted [35], and cells undergo programmed death [30]. In this context, RIP1 is deubiquitinated by enzymes such as Cezanne [36] and CYLD [37]. In addition, the complex composed of TRADD and RIP1 moves to the cytosol to form complex II. FADD is recruited to TRADD by the DD-DD interaction and binds caspase-8 [30]. Notably, when caspase- 8 activity is inhibited or its expression is extinguished, DISC is unable to trigger the apoptotic signaling pathway, but TNFR1 or CD95 stimulation leads to the activation of another cell death signal, necroptosis $[38,39]$. To prevent the induction of the necroptotic signal, caspase8 cleaves and inactivates RIP1 and RIP3 [40]. The fine-tuned control of necroptosis by members of the apoptotic signaling pathway has been elegantly confirmed by experiments showing that the embryonic lethality of mice harboring single $\mathrm{KO}$ of caspase- 8 or FADD can be rescued by an additional KO of the RIP3 gene [41-43].

\subsection{TNF/TNFR: a gold mine for therapeutic tools}

Many studies of TNF- $\alpha$ have demonstrated its pivotal role in fueling inflammation, a multistep process that promotes autoimmunity (e.g., rheumatoid arthritis, ankylosing 
spondylitis, Crohn's disease, psoriasis, and refractory asthma) and cancer. Many TNF inhibitors, such as neutralizing monoclonal antibodies (mAbs) (e.g., infliximab, adalimumab, and golimumab) have been developed to treat these chronic inflammatory disorders, demonstrating that altering ligand/receptor interactions with neutralizing mAbs is an invaluable strategy for treating certain chronic inflammatory disorders. Other TNF- $\alpha$ antagonists, such as etanercept, a TNFR2-immunoglobulin Fc fusion protein, can improve the clinical course of rheumatoid arthritis [44].

A large and growing body of evidence has contributed to elucidation of the molecular mechanisms underlying induction of apoptotic and non-apoptotic signaling pathways by TNFR1, and also provided clues regarding how the receptor can switch from one signal to the other. However, the mechanistic links involved in implementation of non-apoptotic signaling pathways by CD95 remain elusive. However, several recent findings have revealed its proinflammatory effects [45-51].

\section{CD95: a death receptor?}

In 1989, identification of the mAb APO-1 by Peter Krammer et al. revealed the existence of a $52 \mathrm{kDa}$ protein whose aggregation resulted in transmission of an apoptotic signal in cancer cells [52]. This receptor was cloned in 1991 by Nagata and colleagues, who named it Fas (CD95 or APO-1) [8]. Its ligand, CD95L, was cloned in 1993 by the same group, and was found to be primarily expressed at the surface of activated $\mathrm{T}$ lymphocytes [53] and natural killer (NK) cells [54]; however, its expression was also detected in tissues in which the presence of acute or chronic inflammation is highly undesirable, including the eyes [55] and testes [56].

\subsection{Structure /function}


The CD95 gene (APT1) consists of nine exons encoding a type I transmembrane protein harboring three CRDs, with exon 6 encoding the transmembrane domain [57] (Figure 1). Under denaturing conditions, CD95 migrates as a 40-50 kDa protein on SDS-PAGE. Similar to the TNF receptor [25], CD95 is pre-associated at the plasma membrane as a homotrimer, and this quaternary structure is mandatory for transmission of apoptotic signals in the presence of CD95L $[19,20]$. Homotrimerization of CD95 occurs mainly through homotypic interactions involving the CD95-CRD1 domain [18-20]. Binding of CD95L or agonistic antiCD95 mAbs to CD95 alters the receptor's conformation and the extent to which the receptor is multimerized at the plasma membrane [58]. The intracellular region of CD95 encompasses an 80 amino-acid stretch designated as the DD (Figure 1), which consists of six anti-parallel $\alpha$-helices [59]. Upon addition of CD95L, CD95 undergoes conformational modification of the DD, inducing a shift of helix 6 and fusion with helix 5, promoting both oligomerization of the receptor and recruitment of the adaptor protein FADD [60]. One consequence of the opening of the globular structure of CD95 is that the receptor becomes connected through this bridge, which increases the extent of its homo-aggregation. This long helix allows stabilization of the complex by recruitment of FADD. The CD95-DD:FADD-DD crystal structure provides several insights into the formation of the large CD95 clusters observed by imaging or biochemical methods in cells stimulated with CD95L. In addition, the structure also confirms that alteration in the conformation of CD95 plays an instrumental role in signal induction [60]. However, the idea of an elongated C-terminal $\alpha$-helix favoring the cis-dimerization of CD95-DD was challenged by Driscoll et al., who did not observe the fusion of the last two helices at a more neutral $\mathrm{pH}(\mathrm{pH} 6.2)$, in contrast to the acidic condition $(\mathrm{pH} 4)$ used in the initial study in which Scott et al. resolved the CD95-DD:FADD-DD structure [60]. At pH 6.2, association of CD95 predominantly interacted with FADD in a 5:5 complex, which arose via a polymerization mechanism involving three types of asymmetric interactions, but without 
major alteration of the DD globular structure $[61,62]$. It is likely that the low-pH condition used by Scott et al. altered the conformation of CD95, resulting in the formation of nonphysiological CD95:FADD oligomers [60]. Nonetheless, we cannot rule out the possibility that a local decrease in intracellular $\mathrm{pH}$ affects the initial steps of the CD95 signaling pathway in vivo, e.g., by promoting the opening of the CD95-DD and eventually contributing to formation of a complex that elicits a sequence of events distinct from that occurring at physiologic $\mathrm{pH}$.

Once docked on CD95-DD, FADD self-associates [63], and binds procaspases-8 and -10, which are auto-processed and released in the cytosol as active caspases. Once activated, these caspases cleave many substrates, ultimately leading to the execution of the apoptotic program and cell death. The complex CD95/FADD/caspase-8/-10 is called DISC (Figure 2) [6]. Due to the importance of DISC formation to cell fate, it is not surprising that numerous cellular and viral proteins have evolved to hamper the formation of this structure: for example, both FLIP $[64,65]$ and PED/PEA-15 [66] interfere with the recruitment of caspase-8/-10 (Figure 2).

\subsection{Type I /II signaling pathways}

Following the discovery of CD95 and the elucidation of the initial steps in its signaling pathway, Peter and colleagues reported that cells can be divided in to two groups with regard to the kinetics with which they respond to CD95-mediated apoptotic signals, the magnitude of DISC formation, and the role played by the mitochondrion in this pathway [67]. DISC formation occurs rapidly and efficiently in type I cells, resulting in the release of a large amount of activated caspase- 8 in the cytosol, whereas type II cells have difficulty forming this complex, and the amount of active caspase- 8 is insufficient to directly activate the effector caspases-3 and -7 [67]. Nonetheless, type II cells experience cell death upon CD95 
engagement and are even more sensitive to CD95-mediated apoptotic signals than type I cells [67-69]. This discrepancy can be partly explained by the fact that the low level of activated caspase-8 in type II cells is sufficient to cleave BID, a BH3-only protein, which constitutes the molecular link between caspase- 8 activation and the apoptotic activity of mitochondria. Indeed, after cleavage by caspase-8, truncated BID (tBID) translocates to mitochondria, where it triggers the release of pro-apoptotic factors (Figure 2) [70, 71]. Although CD95 stimulation activates the mitochondrion-dependent apoptotic signal in type I and type II cells, it seems that only type II cells are addicted to this signal, because they contain higher levels of the caspase-3 inhibitor XIAP than type I cells [72]. Several members of the inhibitor of apoptosis (IAP) protein family, XIAP, c-IAP1, and c-IAP2 inhibit caspase-3, -7 [73, 74], and pro-caspase-9 [75] activity by direct binding, thereby preventing access to substrates. Furthermore, XIAP can function as an E3 ligase; this activity is involved in the ubiquitination of active caspase-3 and its subsequent degradation by the proteasome [76]. To detach XIAP from caspase- 3 and restore the apoptotic signal, cells require the release of SMAC/DIABLO (second mitochondria-derived activator of caspase/direct IAP-binding protein with low PI) by the mitochondrion $[77,78]$, explaining why type II cells are more 'addicted' to this organelle than type I cells (Figure 2).

To summarize, DISC formation and IAP amount are two cellular markers that allow a clear discrimination between type I and type II cells. Even though IAP overexpression can account for the mitochondrial dependency observed in type II cells, it remains unclear why DISC formation is hampered in type II cells and/or augmented in their type I counterparts. Recently, high activity of the lipid kinase phosphoinositide 3-kinase (PI3K) or downregulation of its neutralizing phosphatase, phosphatase and tensin homologue on chromosome 10 (PTEN), were observed in type II cells, whereas this signal is blocked in type I cell lines $[79,80]$. The PI3K signaling pathway prevents the aggregation of CD95 [81], probably by 
retaining the receptor outside of lipid rafts $[79,82]$. PEA-15, also known as PED, is a protein containing a death effector domain (DED) that inhibits the CD95 and TNFR1 apoptotic signals (Figure 2) [66]. Activation of PI3K and its downstream effector, serine-threonine kinase Akt, leads to phosphorylation of PEA-15 at serine 116 [79, 82]; this post-translational modification promotes its interaction with FADD, ultimately inhibiting DISC formation [83, 84].

Notably, the existence of type I and type II cells is not only an in vitro observation, but has been identified physiologically in the human body. CD95-mediated apoptotic signals cannot be altered in thymocytes or activated T cells expressing a Bcl-2 transgene, consistent with the type I nature of these cells [85], whereas hepatocytes expressing the same transgene resist CD95-induced apoptosis and thus behave as type II cells [86, 87].

\subsection{What can we learn from CD95 mutations?}

\subsubsection{Human.}

Germinal mutations in APT1 have been reported in patients with autoimmune lymphoproliferative syndrome type Ia (ALPS, also called Canale-Smith syndrome) [88-90]. ALPS patients exhibit chronic lymphadenopathy and splenomegaly and expanded populations of double-negative $\alpha / \beta$ T lymphocytes $\square \mathrm{CD}^{+} \mathrm{CD}^{-} \mathrm{CD}^{-}$), and often develop autoimmunity $[88,89,91,92]$. In agreement with the notion that CD95 behaves as a tumor suppressor, ALPS patients display an increased risk of Hodgkin and non-Hodgkin lymphoma [93]. The predominance of post-germinal center (GC) lymphomas in patients with either germ line or somatic CD95 mutations can be explained by the fact that, inside germinal centers of the secondary lymphoid follicles, the CD95 signal plays a pivotal role in the deletion of selfreactive maturing B lymphocytes [94]; in addition, APT1 belongs to a set of rare genes (i.e., 
PIM1, c-myc, PAX5, RhoH/TTF, and Bcl-6) subject to somatic hypermutation [95, 96], which may affect its biological function. In addition to post-GC lymphomas, tumors of various histological origins have been shown to exhibit significant numbers of mutations in the CD95 gene (reviewed in [51]). Extensive analysis of CD95 mutations and their distribution in APT1 reveals that, with some exceptions, most are gathered in exons 8 and 9, which encode the CD95 intracellular region (Figure 3) [97]. Remarkably, most of these mutations are heterozygous, mainly localized in CD95-DD, and lead to inhibition of the CD95-mediated apoptotic signal. Indeed, in agreement with the notion that CD95 is expressed at the plasma membrane as a pre-associated homotrimer [19, 20], formation of heterocomplexes containing wild-type and mutated CD95 prevents FADD recruitment and dominantly abrogates the initiation of the apoptotic signal.

Extensive analysis of the positions of CD95 mutations described in the literature has revealed mutation "hot spots" in the CD95 sequence (Figure 3). Among these hot spots, arginine 234, aspartic acid 244, and valine 251 account for a considerable proportion of the documented CD95 mutations. Indeed, among the 189 mutations annotated in the 335 amino acids of CD95, $30(\sim 16 \%)$ are localized in one of these three amino acids (Figure 3). The pivotal roles played by these amino acids in stabilization or formation of intra- and inter-bridges between CD95 and FADD may explain the existence of these hot spots. For instance, both R234 and D244 contribute to homotypic aggregation of the receptor and FADD recruitment [59]. Nevertheless, the observation of death-domain hot spots contradicts the study of Scott and colleagues, who demonstrated that the region of CD95-DD that interacts with the FADD-DD extends over a dispersed surface and is mediated by a large number of low-affinity interactions [60].

Most ALPS type Ia patients affected by malignancies do not undergo loss of heterozygosity (LOH), leading some authors to hypothesize that preservation of a wild-type allele may 
contribute to carcinogenesis $[98,99]$. In the same vein, expression of a unique mutated CD95 allele blocks the induction of apoptotic signals, but fails to block non-apoptotic signals such as NF- $\kappa \mathrm{B}$ and MAPK [98, 99], whose induction promotes invasiveness in tumor cells [97, 100]. In addition, mutations in the intracellular CD95-DD result in more highly penetrant ALPS phenotype features in mutation-bearing relatives than mutations in the extracellular domain. These results suggest that unlike DD mutations, CD95 mutations localized outside the DD somehow block apoptotic signaling but fail to promote non-apoptotic pathways that may contribute to disease aggressiveness.

\subsubsection{Mouse models.}

Three mouse models exist in which either CD95L affinity for CD95 is reduced (due to the germline mutation F273L in CD95L, called generalized lymphoproliferative disease [gld], which decreases CD95L binding to CD95) [101, 102]), the level of CD95 expression is downregulated (due to an insertion of a retrotransposon in intron 2 of the receptor gene, these mice are called lymphoproliferation [Lpr] [103-105]), or DISC formation is hampered (due to a spontaneous mutation inside the CD95 DD at position 238, specifically, replacement of the valine 238 with asparagine; these mice are called $\mathrm{lpr}^{\mathrm{cg}}$ for $l p r$ gene complementing gld [106]). These mice have provided valuable insights into the pivotal role played by CD95 and CD95L in immune surveillance and immune tolerance [107]. In an attempt to simplify, some authors associated the phenotypes observed in these $1 \mathrm{pr}, \mathrm{lpr}^{\mathrm{cg}}$ or gld mice with the complete loss of CD95 or CD95L [108]. However, conclusions must be drawn with caution, due to subtle differences between the phenotypes of spontaneous mouse models and genetically engineered mice. Indeed, in Lpr mice, insertion of an early transposon in intron 2 of CD95 causes

premature termination of the CD95 transcript [104], which is leaky; consequently, CD95 
mRNA and protein can be detected in mice homozygous for the spontaneous mutation [109, 110]. Also, the DD mutation in $\mathrm{Lpr}^{\mathrm{cg}}$ mice reduces FADD recruitment but does not abrogate it [111]. Furthermore, CD95 can still interact with CD95L harboring the gld mutation, albeit somewhat more weakly than wild-type CD95L [112]. Finally, $\mathrm{lpr}, \mathrm{lpr}^{\mathrm{cg}}$, and gld mice overexpress CD95L relative to their wild-type counterparts [113]. Using $\mathrm{T}$ lymphocytes from ALPS type Ia patients or Lpr mice, we confirmed that far less intact CD95 is required to activate NF- $\mathrm{kB}$ than to induce apoptosis; therefore, although a single wild-type allele cannot restore cell death induction in these cells, it is sufficient to transduce NF- $\kappa \mathrm{B}$ and MAPK cues $[98,99]$. Overall, these observations support the idea that the biological roles ascribed to the CD95/CD95L pair, based on the analysis of these patients and mouse models, may correspond to the additive effects of the receptor's inability to induce cell death and its tendency to implement non-apoptotic signals.

A recent study elegantly showed that elimination of the remaining allele in cancer cells leads to the induction of an unconventional cell death program called "death induced by CD95R/L elimination” (DICE) [114].

These findings highlight the fact that distinct activation thresholds exist in the process of CD95 engagement. Although complete loss of CD95 expression in cancer cells leads to cell death, one wild-type allele (low activation threshold) is sufficient to elicit non-apoptotic signaling pathways, and the second allele (high activation threshold) is required to implement the canonical apoptotic signal $[98,115]$. However, this rule suffers from an exception: metalloprotease-cleaved CD95L implements non-apoptotic signals in cells expressing two wild-type alleles of CD95 [48, 50, 116, 117] (further discussed in 3.6.2). In summary, because the characterization of CD95/CD95L biological roles has been carried out mainly by considering the default of apoptosis in ALPS type Ia patients and mouse models, we believe it is important to carefully reconsider these conclusions by integrating the notion that exposure 
of these cells to CD95L will also lead to a chronic activation of non-apoptotic signaling pathways [99]. To better appreciate the complexity of the pathophysiological roles of CD95 and its ligand, it is therefore more appropriate to use conditional and tissue-specific CD95 and CD95L KO mice.

\subsection{Regulation of the Initial Steps of CD95-mediated Signaling}

\subsubsection{Lipid rafts}

In addition to CD95 down-regulation or expression of a mutated allele of the receptor, alteration of the plasma membrane distribution of CD95 represents an additional mechanism by which tumor cells could develop resistance to CD95L-expressing immune cells. The plasma membrane is a heterogeneous lipid bilayer comprising compacted or liquid-ordered domains, called microdomains, lipid rafts, or detergent-resistant microdomains (DRMs). These domains, which are enriched in ceramides, have been described as floating in a more fluid or liquid-disordered two-dimensional (2-D) lipid bilayer [118]. A series of elegant experiments showed that although CD95 is mostly excluded from lipid rafts in activated T lymphocytes, TCR-dependent re-activation of these cells leads to rapid distribution of the death receptor into lipid rafts [119]. This CD95 compartmentalization contributes to a reduction in the apoptotic threshold, leading to clonotypic elimination of activated $\mathrm{T}$ lymphocytes through activation of the CD95-mediated apoptotic signal [119]. Similarly, the reorganization of CD95 into DRMs can occur independently of ligand upon addition of certain chemotherapeutic drugs (e.g., rituximab [120], resveratrol [121, 122], edelfosine [79, 123, 124], aplidin [125], perifosine [124], and cisplatin [126]). The molecular cascades underlying this process remain elusive. Nevertheless, a growing body of evidence leads us to postulate that alteration of intracellular signaling pathway(s), such as the aforementioned 
PI3K signal [79, 82], may change biophysical properties of the plasma membrane, such as membrane fluidity, which in turn may facilitate CD95 clustering into large lipid raft-enriched platforms, favoring DISC formation and induction of the apoptotic program [82].

\subsubsection{Post-translational modifications}

Accumulation of CD95 mutations is not the only mechanism by which malignant cells inhibit the extrinsic signaling pathway. Post-translational modifications in the intracellular tail of CD95, such as reversible oxidation or covalent attachment of palmitic acid, alter the plasma membrane distribution of CD95 and thereby its downstream signaling. For instance, Sglutathionylation of mouse CD95 at cysteine 294 promotes clustering of CD95 and its distribution into lipid rafts [127]. This amino acid is conserved in the human CD95 sequence and corresponds to cysteine 304 (or C288 when the 16 amino-acid signal peptide is taken into consideration $[8,128])$. Interestingly, Janssen-Heininger and colleagues emphasize that death receptor gluthationylation occurs downstream of activation of caspase- 8 and -3 ; the catalytic activities of these caspases damage the thiol transferase glutaredoxin 1 (Grx1) [127]. One consequence of Grx1 inactivation is accumulation of glutathionylated CD95, which clusters into lipid rafts, thereby sensitizing cells to CD95-mediated apoptotic signals. Based on these findings, caspase- 8 activation occurs prior to aggregation of CD95 and redistribution into lipid rafts, both of which are required to form the DISC and subsequently activate larger amounts of caspase-8. In agreement with these observations, activation of caspase- 8 occurs in a two-step process. First, a small amount of activated caspase-8 $(<1 \%)$ is generated immediately when CD95L interacts with CD95, resulting in acid sphingomyelinase (ASM) activation, ceramide production, and CD95 clustering; these in turn promote DISC formation 
and the burst of caspase- 8 processing that is essential for implementation of the apoptotic program [129].

S-glutathionylation consists of a bond between a reactive Cys-thiol and reduced glutathione (GSH), a tripeptide consisting of glycine, cysteine, and glutamate. Attachment of this group to a protein alters its structure and function in a manner similar to the addition of a phosphate [130]. S-glutathionylation is not the only post-translational modification of a cysteine in CD95: S-nitrosylation of cysteine 199 (corresponding to C183 after subtraction of signal peptide sequence) and 304 (C288) in colon and breast tumor cells also promotes the redistribution of CD95 into DRMs, formation of the DISC, and the transmission of the apoptotic signal [131].

Two reports have demonstrated that covalent coupling of a 16-carbon fatty acid (palmitic acid) to cysteine 199 (C183) elicits the redistribution of CD95 into DRMs, the formation of SDS-stable CD95 microaggregates resistant to denaturing and reducing treatments, and internalization of the receptor $[132,133]$. Although the order of these events remains to be precisely determined, it is clear that these molecular steps play a critical role in the implementation of apoptotic signals.

As with S-nitrosylation, both the aforementioned S-glutathionylation at C304 (C288) and palmitoylation at $\mathrm{C} 199$ (C183) promote the partition of CD95 into lipid rafts and augment the subsequent apoptotic signal. Further investigation is required to determine whether these posttranslational modifications are redundant, and occur simultaneously in dying cells, or instead are elicited in a cell-specific and/or in a microenvironment-specific manner. Understanding the molecular mechanisms controlling these post-translational modifications would be of great value in efforts to identify the mechanisms by which tumor cells block them, leading to resistance to the extrinsic signaling pathway. 
Soon after CD95 was cloned, several groups investigated phosphorylation of this protein on serine/threonine and tyrosine and explored its biological role. Although serine/threonine phosphorylation may participate in the implementation of the CD95 signal, these authors mainly focused on the role of tyrosine phosphorylation in the cell death pathway. Phosphorylation can occur on two tyrosines located in the first (Y232, corresponding to Y216 starting from the first amino acid after the signal peptide) and fifth (Y291/Y275) $\alpha$-helices of CD95-DD [134]. Y275 is located within a conserved YXXL motif reminiscent of the conserved 'I/VxYxxL' motif, termed the immunoreceptor tyrosine-based inhibitory motif (ITIM), which is responsible for the recruitment and activation of inhibitory phosphatases [135]. By recruiting the src homology domain 2 (SH2)-containing tyrosine phosphatase-1 (SHP-1), Y275 phosphorylation promotes CD95-mediated cell death in T cells [136] and counteracts the GM-CSF-driven pro-survival signals in neutrophils [135]. Notably, this $\mathrm{Y}^{275} \mathrm{DTL}$ cytoplasmic domain is also a putative consensus YXXF sequence for AP-2 binding [137], which is instrumental in CD95 internalization (see below and [138]). Consistent with this, replacement of Y275 by a phenylalanine inhibits CD95 internalization and thereby blocks the induction of apoptosis, but does not affect non-apoptotic responses [138]. In addition, tyrosine phosphorylation of CD95 promotes the recruitment of the src kinases Fyn and Lyn through their SH2 domains, thereby promoting cell death [139, 140]. Accordingly, it is tempting to speculate that Y275 phosphorylation may guide the receptor through the induction of the apoptotic signal at the expense of non-apoptotic pathways. These data raise some questions about the identity of the tyrosine kinase involved in Y275 phosphorylation, the order of the molecular events leading to phosphatase and src kinase recruitment, and their respective roles in the CD95 signaling pathway.

\subsubsection{CD95 internalization}


A powerful magnetic method for isolating receptor-containing endocytic vesicles was used to show that CD95 promptly associates with endosomal and lysosomal markers upon incubation of cells with agonistic anti-CD95 mAb [138]. In addition, expression of a CD95 mutant in which the DD-located tyrosine 291 (Y275) is changed to phenylalanine does not seem to alter the capacity to bind FADD, but instead compromises CD95L-mediated CD95 internalization occurring through an AP-2/clathrin-driven endocytic pathway [138]. More strikingly, expression of the internalization-defective CD95 mutant Y291F abrogates the transmission of apoptotic signals, but fails to block the non-apoptotic signaling pathways (i.e., NF- $\mathrm{B}$ and ERK); indeed, the mutant even promotes these pathways (Figure 3). These findings highlight the presence of a region in the DD, which interacts with AP2 and promotes a clathrindependent endocytic pathway in a FADD-independent manner. The role of palmitoylation in the AP2/clathrin-driven internalization of CD95 remains to be elucidated.

\subsection{4 $\mathrm{Ca}^{2+}$ response}

A recent study demonstrated that CD95 engagement evokes rapid and transient $\mathrm{Ca}^{2+}$ signaling, which stimulates the recruitment of protein kinase C- $\beta 2$ (PKC- $\beta 2$ ) from the cytosol to the DISC[141]. This kinase transiently halts DISC formation, providing a checkpoint before the irreversible commitment to cell death [142]. These findings raised two important questions: what are the $\mathrm{Ca}^{2+}$-dependent molecular mechanisms transiently inhibiting DISC formation, and do tumor cells use this signal to escape the immune response and/or resist chemotherapy?

\subsection{Programmed necrosis, also known as necroptosis}


In 1998, inhibition of caspase activity was shown to sensitize the fibroblastic L929 cell line to TNF-mediated necrotic cell death [39]. With respect to the CD95 signal, Tschopp et al. showed that FADD and RIP1 participate in the implementation of a non-apoptotic signaling pathway that leads to a necrotic morphology associated with loss of plasma membrane integrity but not with chromatin condensation [38]. Of note, BID cleavage was not observed in the context of this necrotic signal. Whereas FADD plays a crucial role in both apoptotic and necrotic pathways, RIP1 recruitment to CD95 occurs independently of this adaptor protein. Indeed, yeast two-hybrid experiments showed that RIP1 can bind directly to the CD95 DD, whereas this interaction is lost when a bait corresponding to mutated CD95-DD (replacement of Val 238 to Asn) is used [143]. In addition, RIP3 (RIPK3, a member of the RIP kinase family) is an indispensable factor for the induction of the necrotic signaling pathway [70-72]. Identification of necrostatin, a chemical inhibitor of necroptosis [144] that specifically inhibits RIP1 kinase activity [145], has accelerated the pace of discovery in this field of cell death. The apoptosis and necroptosis pathways interact: for instance, caspase- 8 exerts a potent inhibitory effect on CD95 and TNFR1-mediated necroptosis [146] through its ability to process and inactivate RIP1 and RIP3 [147, 148]. At least in the case of TNF signaling, the necrotic signal relies on the activity of CYLD, a deubiquitinating enzyme that is also cleaved and inactivated by caspase-8 [149].

Overall, these findings suggest that the apoptotic machinery controls the necrotic pathway. This concept was recently confirmed by the results of in vivo double-KO experiments [41-43, 150]. Indeed, FADD and caspase- 8 can be considered to be a prosurvival factor, mainly because both of these two "apoptotic" molecules inhibit the RIP1/RIP3-dependent necrotic signal; consequently, their loss unleashes the necroptotic program and leads to embryonic lethality. However, most studies on necroptosis have focused on the TNF signaling pathway, whereas the mechanism by which CD95 elicits this cell death 
pathway, as well as how this receptor switches between non-apoptotic, apoptotic, and necroptotic signals, remains to be elucidated. Importantly, the impact of each type of cell death on antigen presentation, and on the efficiency of immune response after elimination of infected or transformed cells, also remains unclear.

\subsection{CD95L, an Inflammatory/Oncogenic Cytokine?}

\subsubsection{A ligand that creates immune privilege}

The transmembrane CD95L (CD178/FasL) is present on the surface of activated lymphocytes [102] and NK cells [151], where it orchestrates the elimination of transformed and infected cells. In addition, CD95L is expressed on the surface of neurons [152], corneal epithelia and endothelia [55, 153], and Sertoli cells [56], where it acts to prevent the infiltration of immune cells and thereby inhibit the spread of inflammation in these sensitive organs (i.e., brain, eyes, and testis, respectively), commonly referred to as "immune-privileged" sites. The initial description of physiological immune privilege was followed by an understanding of tumormediated immune privilege: two groups independently reported that the ectopic expression of CD95L by malignant cells participated in the elimination of infiltrating $\mathrm{T}$ lymphocytes, and could thus play a role in the establishment of a tumor site to which immune cells are denied access $[154,155]$. However, these observations are controversial, because ectopic expression of CD95L in allogenic transplant of $\beta$-islets $[156,157]$ and in tumor cell lines $[158]$ led to a more rapid elimination of these cells relative to control cells, at least in part due to increased infiltration of neutrophils and macrophages endowed with antitumor activity.

\subsection{2 (At least) two different ligands and two different signals}


Among the weapons at the disposal of immune cells is transmembrane CD95L, which contributes to the elimination of pre-tumor cells. Therefore, pre-tumor cells that escape immune surveillance will tend to have developed resistance to CD95, a process termed immunoediting [159]. In other words, the influence of the immune system on pre-tumor cells will select for malignant cells with elevated resistance to the CD95L-induced signal. As previously mentioned, these alterations to the CD95 signal not only block the CD95-mediated apoptosis, but also promote the transmission of non-apoptotic signals by CD95L, which may also play a critical role in carcinogenesis [98-100, 160]. In support of this hypothesis, complete loss of CD95 expression is rarely observed in malignant cells [161].

Accumulating evidence indicates that the apoptotic ligand CD95L behaves as a chemoattractant for neutrophils, macrophages [47, 157, 158], T lymphocytes [50], and malignant cells in which the CD95-mediated apoptotic signal is non-productive $[100,116]$. Nonetheless, the biological role of CD95L must be further clarified, given that in pathophysiological settings, the ligand is present in at least two forms with different stoichiometries. CD95L is a transmembrane cytokine whose ectodomain can be cleaved by metalloproteases such as MMP3[162], MMP7[163], MMP9[164], and ADAM-10 (A disintegrin and metalloproteinase 10) $[165,166]$, and then released into the bloodstream as a soluble ligand. Based on data showing that hexameric CD95L represents the minimal level of self-association required to signal apoptosis [167], and that cleavage by metalloproteases releases an homotrimeric ligand $[167,168]$, this soluble ligand has long been considered to be an inert molecule that competes with its membrane-bound counterpart for CD95 binding, thereby antagonizing the death signal $[168,169]$. However, recent work has demonstrated that this metalloprotease-cleaved CD95L (cl-CD95L) actively aggravates inflammation and autoimmunity in patients affected by systemic lupus erythematosus (SLE) by inducing the non-apoptotic NF- $\kappa \mathrm{B}$ and PI3K [48, 50] signaling pathways (Figure 4). In contrast to the case 
of transmembrane CD95L, induction of the PI3K signaling pathway by its metalloproteasecleaved counterpart occurs through the formation of a molecular complex devoid of FADD and caspase-8 that instead recruits the src kinase c-yes $[50,116]$; this unconventional receptosome was designated the motility-inducing signaling complex (MISC) [50, 117](Figure 4). Even though we did not detect any trace of caspase-8 in MISC, this enzyme has been shown to participate in cell migration. The protease activity of caspase- 8 can be abolished by phosphorylation at tyrosine 380 by src kinase [170]. This post-translational modification was observed in cells stimulated with EGF and in colon cancer cells with constitutive activation of src; from a molecular standpoint, the modification does not alter caspase homodimerization or recruitment in DISC [170]. Moreover, the epidermal growth factor receptor (EGFR)-driven phosphorylation of caspase-8 at Y380 turns out to potently induce the PI3K signaling pathway by recruiting the PI3K adaptor p85 alpha subunit [171]. Ultimately, caspase- 8 phosphorylation triggers cell migration. Nonetheless, it is noteworthy that CD95-induced migration and invasion does not appear to require an intact DD (reviewed in [172]), suggesting either that the caspase-8-dependent mode of cell migration reflects the action of an alternative signal mediated by death receptors or that it only participates in nondeath receptor-induced cell motility. It would be interesting to address this question in the future. At present, we can only surmise that phosphorylation of caspase- 8 at Y380 following EGFR stimulation primes certain cancer cells to become unresponsive to the apoptotic signal triggered by cytotoxic CD95L, and meanwhile promotes cell migration, an essential event in cancer cell metastasis (Figure 4). We recently showed that CD95 implements the PI3K signaling pathway by recruiting EGFR. This CD95-dependent EGFR activation relies on the recruitment of the NADPH oxidase 3 (Nox3), the production of reactive oxygen species, which in turn activate the src kinase c-yes [117]. In triple-negative breast cancer cells exposed to metalloprotease-cleaved CD95L, c-yes activation is instrumental in forming an EGFR- 
containing MISC, and this receptor tyrosine kinase (RTK) orchestrates the activation of PI3K in an EGF-independent manner (Figure 4). These data are in accordance with a recent study showing that another RTK, platelet-derived growth factor receptor- $\beta$, is recruited in colon cancer cells exposed to CD95L and thereby triggers cell migration [173]. Accordingly, we postulate that RTK recruitment is a common process in CD95 stimulation that can simultaneously inhibit the apoptotic signal by phosphorylating DISC-recruited caspase- 8 , and promote cell motility by activating the PI3K signaling pathway. This hypothesis will be investigated further in future work.

In a similar manner, a reduction in the plasma membrane level of CD95 or expression of a mutated CD95 allele, as observed in ALPS patients and malignant cells, inhibits the implementation of the apoptotic signal but does not affect the transmission of non-apoptotic signals, e.g., via NF- $\mathrm{B}$, MAPK, and PI3K [98, 99, 161], suggesting that these signals may stem from a domain other than CD95-DD, or are elicited at different thresholds. In summary, although the CD95/CD95L interaction can eliminate malignant cells by promoting formation of the DISC, or contribute to carcinogenesis by sustaining inflammation and/or inducing metastatic dissemination $[47,48,50,100,116,161,174]$, the molecular mechanisms underlying the switch between these different signaling pathways remain enigmatic. An important question to be addressed is how the magnitude of CD95 aggregation regulates the formation of "Death"- vs. "Motility"-ISCs. Answering these questions will lead to the development of new therapeutic agents with the ability to contain the spread of inflammation or impede carcinogenesis, at least in pathologies associated with increased soluble CD95L, such as cancers (e.g., pancreatic cancer [175], large granular lymphocytic leukemia, breast cancer [176], and NK-cell lymphoma, [177]) or autoimmune disorders (e.g., rheumatoid arthritis and osteoarthritis [178], and graft-versus-host-disease (GVDH) [179, 180] or SLE[50, 181]). Together, these studies support the notion that the death function of CD95 corresponds 
to its "day job" while the receptor may act as "a night killer" by fueling inflammation in certain pathophysiological contexts.

Strikingly, although the soluble form of CD95L generated by MMP7 (cleavage site inside the ${ }^{113} \mathrm{ELR}^{115}$ sequence, Figure 5) induces apoptosis [163], its counterpart processed between serine 126 and leucine 127 does not [48, 50, 168]. To explain this discrepancy, we speculate that the different quaternary structures of naturally processed CD95L molecules underlie the implementation of death-inducing vs. non-death-inducing signaling complexes. Consistent with this notion, soluble CD95L incubated in the bronchoalveolar lavage (BAL) fluid of patients suffering from acute respiratory distress syndrome (ARDS) undergoes oxidation at methionines 224 and 225 (Figure 5), promoting aggregation of the soluble ligand and boosting its cytotoxic activity [182]. The same authors observed that the stalk region of CD95L, corresponding to amino acids 103-136 and encompassing the metalloprotease cleavage sites (Figure 5), participates in the multimerization of CD95L, accounting for the damage to the lung epithelium that occurs in ARDS [182]. Of note, in ARDS BAL fluid, additional oxidation occurs at methionine 121 (Figure 5), which prevents the processing of CD95L by MMP7, potentially explaining why this cytotoxic ligand retains its stalk region [182]. Nonetheless, preservation of this region in soluble CD95L raises the possibility that an unidentified MMP7-independent cleavage site exists in the juxtamembrane region of CD95L, near the plasma membrane, or alternatively that the ligand detected in ARDS patients corresponds to full-length CD95L embedded in exosomes [183, 184]. Indeed, this peculiar exosome-bound CD95L is sometimes expressed by human prostate cancer cells (i.e., LNCaP), and it evokes apoptosis in activated T lymphocytes [185].

Overall, these findings emphasize the importance of finely characterizing the quaternary structure of naturally processed CD95L from the sera of patients affected by cancers or chronic/acute inflammatory disorders. Such investigations will improve our understanding of 
the molecular mechanisms set in motion by this ligand, and thus our appreciation of its downstream biological functions. 


\section{Acknowledgements}

This work was supported by grants from INCa, Ligue Contre le Cancer (Comités d'Ille-etVilaine/du Morbihan/des Côtes d'Armor/du Finistère/du Maine et Loire), ARC, Cancéropole Grand Ouest, Région Bretagne, Rennes Métropole. 


\section{References}

[1] E.S. Alnemri, D.J. Livingston, D.W. Nicholson, G. Salvesen, N.A. Thornberry, W.W. Wong, J. Yuan, Human ICE/CED-3 protease nomenclature, Cell, 87 (1996) 171.

[2] M.O. Hengartner, The biochemistry of apoptosis, Nature, 407 (2000) 770-776.

[3] M.P. Boldin, E.E. Varfolomeev, Z. Pancer, I.L. Mett, J.H. Camonis, D. Wallach, A novel protein that interacts with the death domain of Fas/APO1 contains a sequence motif related to the death domain, The Journal of biological chemistry, 270 (1995) 7795-7798.

[4] A.M. Chinnaiyan, K. O'Rourke, M. Tewari, V.M. Dixit, FADD, a novel death domain-containing protein, interacts with the death domain of Fas and initiates apoptosis, Cell, 81 (1995) 505-512.

[5] H. Hsu, J. Xiong, D.V. Goeddel, The TNF receptor 1-associated protein TRADD signals cell death and NF-kappa B activation, Cell, 81 (1995) 495-504.

[6] F.C. Kischkel, S. Hellbardt, I. Behrmann, M. Germer, M. Pawlita, P.H. Krammer, M.E. Peter, Cytotoxicity-dependent APO-1 (Fas/CD95)-associated proteins form a death-inducing signaling complex (DISC) with the receptor, Embo J, 14 (1995) 5579-5588.

[7] P. Li, D. Nijhawan, I. Budihardjo, S.M. Srinivasula, M. Ahmad, E.S. Alnemri, X. Wang, Cytochrome c and dATP-dependent formation of Apaf-1/caspase-9 complex initiates an apoptotic protease cascade, Cell, 91 (1997) 479-489.

[8] N. Itoh, S. Yonehara, A. Ishii, M. Yonehara, S. Mizushima, M. Sameshima, A. Hase, Y. Seto, S. Nagata, The polypeptide encoded by the cDNA for human cell surface antigen Fas can mediate apoptosis, Cell, 66 (1991) 233-243.

[9] H. Loetscher, Y.C. Pan, H.W. Lahm, R. Gentz, M. Brockhaus, H. Tabuchi, W. Lesslauer, Molecular cloning and expression of the human 55 kd tumor necrosis factor receptor, Cell, 61 (1990) 351-359.

[10] G. Pan, K. O'Rourke, A.M. Chinnaiyan, R. Gentz, R. Ebner, J. Ni, V.M. Dixit, The receptor for the cytotoxic ligand TRAIL, Science, 276 (1997) 111-113.

[11] H. Walczak, M.A. Degli-Esposti, R.S. Johnson, P.J. Smolak, J.Y. Waugh, N. Boiani, M.S. Timour, M.J. Gerhart, K.A. Schooley, C.A. Smith, R.G. Goodwin, C.T. Rauch, TRAIL-R2: a novel apoptosismediating receptor for TRAIL, Embo J, 16 (1997) 5386-5397.

[12] G. Pan, J.H. Bauer, V. Haridas, S. Wang, D. Liu, G. Yu, C. Vincenz, B.B. Aggarwal, J. Ni, V.M. Dixit, Identification and functional characterization of DR6, a novel death domain-containing TNF receptor, FEBS Lett, 431 (1998) 351-356.

[13] M.R. Alderson, R.J. Armitage, E. Maraskovsky, T.W. Tough, E. Roux, K. Schooley, F. Ramsdell, D.H. Lynch, Fas transduces activation signals in normal human T lymphocytes, J Exp Med, 178 (1993) 2231-2235.

[14] K. Schulze-Osthoff, P.H. Krammer, W. Droge, Divergent signalling via APO-1/Fas and the TNF receptor, two homologous molecules involved in physiological cell death, EMBO J, 13 (1994) 45874596.

[15] C.A. Smith, T. Farrah, R.G. Goodwin, The TNF receptor superfamily of cellular and viral proteins: activation, costimulation, and death, Cell, 76 (1994) 959-962.

[16] R.M. Locksley, N. Killeen, M.J. Lenardo, The TNF and TNF receptor superfamilies: integrating mammalian biology, Cell, 104 (2001) 487-501.

[17] J.L. Bodmer, P. Schneider, J. Tschopp, The molecular architecture of the TNF superfamily, Trends in biochemical sciences, 27 (2002) 19-26. 
[18] V. Edmond, B. Ghali, A. Penna, J.L. Taupin, S. Daburon, J.F. Moreau, P. Legembre, Precise Mapping of the CD95 Pre-Ligand Assembly Domain, PLoS ONE, 7 (2012) e46236.

[19] G. Papoff, P. Hausler, A. Eramo, M.G. Pagano, G. Di Leve, A. Signore, G. Ruberti, Identification and characterization of a ligand-independent oligomerization domain in the extracellular region of the CD95 death receptor, J Biol Chem, 274 (1999) 38241-38250.

[20] R.M. Siegel, J.K. Frederiksen, D.A. Zacharias, F.K. Chan, M. Johnson, D. Lynch, R.Y. Tsien, M.J. Lenardo, Fas preassociation required for apoptosis signaling and dominant inhibition by pathogenic mutations, Science, 288 (2000) 2354-2357.

[21] N. Itoh, S. Nagata, A novel protein domain required for apoptosis. Mutational analysis of human Fas antigen, J Biol Chem, 268 (1993) 10932-10937.

[22] L.A. Tartaglia, T.M. Ayres, G.H. Wong, D.V. Goeddel, A novel domain within the $55 \mathrm{kd}$ TNF receptor signals cell death, Cell, 74 (1993) 845-853.

[23] W. Tang, Y. Lu, Q.Y. Tian, Y. Zhang, F.J. Guo, G.Y. Liu, N.M. Syed, Y. Lai, E.A. Lin, L. Kong, J. Su, F. Yin, A.H. Ding, A. Zanin-Zhorov, M.L. Dustin, J. Tao, J. Craft, Z. Yin, J.Q. Feng, S.B. Abramson, X.P. Yu, C.J. Liu, The growth factor progranulin binds to TNF receptors and is therapeutic against inflammatory arthritis in mice, Science, 332 (2011) 478-484.

[24] L. Cabal-Hierro, P.S. Lazo, Signal transduction by tumor necrosis factor receptors, Cell Signal, 24 (2012) 1297-1305.

[25] F.K. Chan, H.J. Chun, L. Zheng, R.M. Siegel, K.L. Bui, M.J. Lenardo, A domain in TNF receptors that mediates ligand-independent receptor assembly and signaling, Science, 288 (2000) 2351-2354.

[26] D. Pennica, G.E. Nedwin, J.S. Hayflick, P.H. Seeburg, R. Derynck, M.A. Palladino, W.J. Kohr, B.B. Aggarwal, D.V. Goeddel, Human tumour necrosis factor: precursor structure, expression and homology to lymphotoxin, Nature, 312 (1984) 724-729.

[27] R.A. Black, C.T. Rauch, C.J. Kozlosky, J.J. Peschon, J.L. Slack, M.F. Wolfson, B.J. Castner, K.L. Stocking, P. Reddy, S. Srinivasan, N. Nelson, N. Boiani, K.A. Schooley, M. Gerhart, R. Davis, J.N. Fitzner, R.S. Johnson, R.J. Paxton, C.J. March, D.P. Cerretti, A metalloproteinase disintegrin that releases tumour-necrosis factor-alpha from cells, Nature, 385 (1997) 729-733.

[28] M.L. Moss, S.L. Jin, M.E. Milla, D.M. Bickett, W. Burkhart, H.L. Carter, W.J. Chen, W.C. Clay, J.R. Didsbury, D. Hassler, C.R. Hoffman, T.A. Kost, M.H. Lambert, M.A. Leesnitzer, P. McCauley, G. McGeehan, J. Mitchell, M. Moyer, G. Pahel, W. Rocque, L.K. Overton, F. Schoenen, T. Seaton, J.L. Su, J.D. Becherer, et al., Cloning of a disintegrin metalloproteinase that processes precursor tumournecrosis factor-alpha, Nature, 385 (1997) 733-736.

[29] M. Grell, E. Douni, H. Wajant, M. Lohden, M. Clauss, B. Maxeiner, S. Georgopoulos, W. Lesslauer, G. Kollias, K. Pfizenmaier, P. Scheurich, The transmembrane form of tumor necrosis factor is the prime activating ligand of the $80 \mathrm{kDa}$ tumor necrosis factor receptor, Cell, 83 (1995) 793-802.

[30] O. Micheau, J. Tschopp, Induction of TNF receptor I-mediated apoptosis via two sequential signaling complexes, Cell, 114 (2003) 181-190.

[31] C.Y. Wang, M.W. Mayo, R.G. Korneluk, D.V. Goeddel, A.S. Baldwin, Jr., NF-kappaB antiapoptosis: induction of TRAF1 and TRAF2 and c-IAP1 and c-IAP2 to suppress caspase-8 activation, Science, 281 (1998) 1680-1683.

[32] T.L. Haas, C.H. Emmerich, B. Gerlach, A.C. Schmukle, S.M. Cordier, E. Rieser, R. Feltham, J. Vince, U. Warnken, T. Wenger, R. Koschny, D. Komander, J. Silke, H. Walczak, Recruitment of the linear ubiquitin chain assembly complex stabilizes the TNF-R1 signaling complex and is required for TNFmediated gene induction, Mol Cell, 36 (2009) 831-844.

[33] T. Kirisako, K. Kamei, S. Murata, M. Kato, H. Fukumoto, M. Kanie, S. Sano, F. Tokunaga, K. Tanaka, K. Iwai, A ubiquitin ligase complex assembles linear polyubiquitin chains, Embo J, 25 (2006) 4877-4887.

[34] B. Gerlach, S.M. Cordier, A.C. Schmukle, C.H. Emmerich, E. Rieser, T.L. Haas, A.I. Webb, J.A. Rickard, H. Anderton, W.W. Wong, U. Nachbur, L. Gangoda, U. Warnken, A.W. Purcell, J. Silke, H. Walczak, Linear ubiquitination prevents inflammation and regulates immune signalling, Nature, 471 (2011) 591-596. 
[35] M. Poukkula, A. Kaunisto, V. Hietakangas, K. Denessiouk, T. Katajamaki, M.S. Johnson, L. Sistonen, J.E. Eriksson, Rapid turnover of c-FLIPshort is determined by its unique C-terminal tail, J Biol Chem, 280 (2005) 27345-27355.

[36] K. Enesa, M. Zakkar, H. Chaudhury, A. Luong le, L. Rawlinson, J.C. Mason, D.O. Haskard, J.L. Dean, P.C. Evans, NF-kappaB suppression by the deubiquitinating enzyme Cezanne: a novel negative feedback loop in pro-inflammatory signaling, J Biol Chem, 283 (2008) 7036-7045.

[37] D.R. Green, A. Oberst, C.P. Dillon, R. Weinlich, G.S. Salvesen, RIPK-dependent necrosis and its regulation by caspases: a mystery in five acts, Mol Cell, 44 (2011) 9-16.

[38] N. Holler, R. Zaru, O. Micheau, M. Thome, A. Attinger, S. Valitutti, J.L. Bodmer, P. Schneider, B. Seed, J. Tschopp, Fas triggers an alternative, caspase-8-independent cell death pathway using the kinase RIP as effector molecule, Nat Immunol, 1 (2000) 489-495.

[39] D. Vercammen, R. Beyaert, G. Denecker, V. Goossens, G. Van Loo, W. Declercq, J. Grooten, W. Fiers, P. Vandenabeele, Inhibition of caspases increases the sensitivity of 1929 cells to necrosis mediated by tumor necrosis factor, J Exp Med, 187 (1998) 1477-1485.

[40] Y.S. Cho, S. Challa, D. Moquin, R. Genga, T.D. Ray, M. Guildford, F.K. Chan, Phosphorylationdriven assembly of the RIP1-RIP3 complex regulates programmed necrosis and virus-induced inflammation, Cell, 137 (2009) 1112-1123.

[41] W.J. Kaiser, J.W. Upton, A.B. Long, D. Livingston-Rosanoff, L.P. Daley-Bauer, R. Hakem, T. Caspary, E.S. Mocarski, RIP3 mediates the embryonic lethality of caspase-8-deficient mice, Nature, 471 (2011) 368-372.

[42] A. Oberst, C.P. Dillon, R. Weinlich, L.L. McCormick, P. Fitzgerald, C. Pop, R. Hakem, G.S. Salvesen, D.R. Green, Catalytic activity of the caspase-8-FLIP(L) complex inhibits RIPK3-dependent necrosis, Nature, 471 (2011) 363-367.

[43] P.S. Welz, A. Wullaert, K. Vlantis, V. Kondylis, V. Fernandez-Majada, M. Ermolaeva, P. Kirsch, A. Sterner-Kock, G. van Loo, M. Pasparakis, FADD prevents RIP3-mediated epithelial cell necrosis and chronic intestinal inflammation, Nature, 477 (2011) 330-334.

[44] M. Feldmann, R.N. Maini, Lasker Clinical Medical Research Award. TNF defined as a therapeutic target for rheumatoid arthritis and other autoimmune diseases, Nat Med, 9 (2003) 1245-1250.

[45] J. Desbarats, R.B. Birge, M. Mimouni-Rongy, D.E. Weinstein, J.S. Palerme, M.K. Newell, Fas engagement induces neurite growth through ERK activation and p35 upregulation, Nat Cell Biol, 5 (2003) 118-125.

[46] J. Desbarats, M.K. Newell, Fas engagement accelerates liver regeneration after partial hepatectomy, Nat Med, 6 (2000) 920-923.

[47] E. Letellier, S. Kumar, I. Sancho-Martinez, S. Krauth, A. Funke-Kaiser, S. Laudenklos, K. Konecki, S. Klussmann, N.S. Corsini, S. Kleber, N. Drost, A. Neumann, M. Levi-Strauss, B. Brors, N. Gretz, L. Edler, C. Fischer, O. Hill, M. Thiemann, B. Biglari, S. Karray, A. Martin-Villalba, CD95-ligand on peripheral myeloid cells activates Syk kinase to trigger their recruitment to the inflammatory site, Immunity, 32 (2010) 240-252.

[48] L.A. O' Reilly, L. Tai, L. Lee, E.A. Kruse, S. Grabow, W.D. Fairlie, N.M. Haynes, D.M. Tarlinton, J.G. Zhang, G.T. Belz, M.J. Smyth, P. Bouillet, L. Robb, A. Strasser, Membrane-bound Fas ligand only is essential for Fas-induced apoptosis, Nature, 461 (2009) 659-663.

[49] W. Ruan, C.T. Lee, J. Desbarats, A novel juxtamembrane domain in tumor necrosis factor receptor superfamily molecules activates Rac1 and controls neurite growth, Mol Biol Cell, 19 (2008) 3192-3202.

[50] S. Tauzin, B. Chaigne-Delalande, E. Selva, N. Khadra, S. Daburon, C. Contin-Bordes, P. Blanco, J. Le Seyec, T. Ducret, L. Counillon, J.F. Moreau, P. Hofman, P. Vacher, P. Legembre, The naturally processed CD95L elicits a c-yes/calcium/PI3K-driven cell migration pathway, PLoS Biol, 9 (2011) e1001090.

[51] S. Tauzin, L. Debure, J.F. Moreau, P. Legembre, CD95-mediated cell signaling in cancer: mutations and post-translational modulations, Cellular and molecular life sciences : CMLS, 69 (2012) 1261-1277. 
[52] B.C. Trauth, C. Klas, A.M. Peters, S. Matzku, P. Moller, W. Falk, K.M. Debatin, P.H. Krammer, Monoclonal antibody-mediated tumor regression by induction of apoptosis, Science, 245 (1989) 301305.

[53] T. Suda, T. Takahashi, P. Golstein, S. Nagata, Molecular cloning and expression of the Fas ligand, a novel member of the tumor necrosis factor family, Cell, 75 (1993) 1169-1178.

[54] Y. Oshimi, S. Oda, Y. Honda, S. Nagata, S. Miyazaki, Involvement of Fas ligand and Fas-mediated pathway in the cytotoxicity of human natural killer cells, J Immunol, 157 (1996) 2909-2915.

[55] T.S. Griffith, T. Brunner, S.M. Fletcher, D.R. Green, T.A. Ferguson, Fas ligand-induced apoptosis as a mechanism of immune privilege, Science, 270 (1995) 1189-1192.

[56] D. Bellgrau, D. Gold, H. Selawry, J. Moore, A. Franzusoff, R.C. Duke, A role for CD95 ligand in preventing graft rejection, Nature, 377 (1995) 630-632.

[57] I. Behrmann, H. Walczak, P.H. Krammer, Structure of the human APO-1 gene, Eur J Immunol, 24 (1994) 3057-3062.

[58] I. Lang, A. Fick, V. Schafer, T. Giner, D. Siegmund, H. Wajant, Signaling active CD95 receptor molecules trigger co-translocation of inactive CD95 molecules into lipid rafts, J Biol Chem, 287 (2012) 24026-24042.

[59] B. Huang, M. Eberstadt, E.T. Olejniczak, R.P. Meadows, S.W. Fesik, NMR structure and mutagenesis of the Fas (APO-1/CD95) death domain, Nature, 384 (1996) 638-641.

[60] F.L. Scott, B. Stec, C. Pop, M.K. Dobaczewska, J.J. Lee, E. Monosov, H. Robinson, G.S. Salvesen, R. Schwarzenbacher, S.J. Riedl, The Fas-FADD death domain complex structure unravels signalling by receptor clustering, Nature, 457 (2009) 1019-1022.

[61] D. Esposito, A. Sankar, N. Morgner, C.V. Robinson, K. Rittinger, P.C. Driscoll, Solution NMR investigation of the CD95/FADD homotypic death domain complex suggests lack of engagement of the CD95 C terminus, Structure, 18 (2010) 1378-1390.

[62] L. Wang, J.K. Yang, V. Kabaleeswaran, A.J. Rice, A.C. Cruz, A.Y. Park, Q. Yin, E. Damko, S.B. Jang, S. Raunser, C.V. Robinson, R.M. Siegel, T. Walz, H. Wu, The Fas-FADD death domain complex structure reveals the basis of DISC assembly and disease mutations, Nature structural \& molecular biology, 17 (2010) 1324-1329.

[63] J.R. Muppidi, A.A. Lobito, M. Ramaswamy, J.K. Yang, L. Wang, H. Wu, R.M. Siegel, Homotypic FADD interactions through a conserved RXDLL motif are required for death receptor-induced apoptosis, Cell death and differentiation, 13 (2006) 1641-1650.

[64] M. Irmler, M. Thome, M. Hahne, P. Schneider, K. Hofmann, V. Steiner, J.L. Bodmer, M. Schroter, K. Burns, C. Mattmann, D. Rimoldi, L.E. French, J. Tschopp, Inhibition of death receptor signals by cellular FLIP, Nature, 388 (1997) 190-195.

[65] M. Thome, P. Schneider, K. Hofmann, H. Fickenscher, E. Meinl, F. Neipel, C. Mattmann, K. Burns, J.L. Bodmer, M. Schroter, C. Scaffidi, P.H. Krammer, M.E. Peter, J. Tschopp, Viral FLICE-inhibitory proteins (FLIPs) prevent apoptosis induced by death receptors, Nature, 386 (1997) 517-521.

[66] G. Condorelli, G. Vigliotta, A. Cafieri, A. Trencia, P. Andalo, F. Oriente, C. Miele, M. Caruso, P. Formisano, F. Beguinot, PED/PEA-15: an anti-apoptotic molecule that regulates FAS/TNFR1-induced apoptosis, Oncogene, 18 (1999) 4409-4415.

[67] C. Scaffidi, S. Fulda, A. Srinivasan, C. Friesen, F. Li, K.J. Tomaselli, K.M. Debatin, P.H. Krammer, M.E. Peter, Two CD95 (APO-1/Fas) signaling pathways, Embo J, 17 (1998) 1675-1687.

[68] A. Algeciras-Schimnich, E.M. Pietras, B.C. Barnhart, P. Legembre, S. Vijayan, S.L. Holbeck, M.E. Peter, Two CD95 tumor classes with different sensitivities to antitumor drugs, Proc Natl Acad Sci U S A, 100 (2003) 11445-11450.

[69] B. Chaigne-Delalande, W. Mahfouf, S. Daburon, J.F. Moreau, P. Legembre, CD95 engagement mediates actin-independent and -dependent apoptotic signals, Cell Death Differ, 16 (2009) 16541664.

[70] X.M. Yin, Signal transduction mediated by Bid, a pro-death Bcl-2 family proteins, connects the death receptor and mitochondria apoptosis pathways, Cell Res, 10 (2000) 161-167.

[71] X.M. Yin, K. Wang, A. Gross, Y. Zhao, S. Zinkel, B. Klocke, K.A. Roth, S.J. Korsmeyer, Bid-deficient mice are resistant to Fas-induced hepatocellular apoptosis, Nature, 400 (1999) 886-891. 
[72] P.J. Jost, S. Grabow, D. Gray, M.D. McKenzie, U. Nachbur, D.C. Huang, P. Bouillet, H.E. Thomas, C. Borner, J. Silke, A. Strasser, T. Kaufmann, XIAP discriminates between type I and type II FAS-induced apoptosis, Nature, 460 (2009) 1035-1039.

[73] N. Roy, Q.L. Deveraux, R. Takahashi, G.S. Salvesen, J.C. Reed, The c-IAP-1 and c-IAP-2 proteins are direct inhibitors of specific caspases, Embo J, 16 (1997) 6914-6925.

[74] Q.L. Deveraux, R. Takahashi, G.S. Salvesen, J.C. Reed, X-linked IAP is a direct inhibitor of celldeath proteases, Nature, 388 (1997) 300-304.

[75] Q.L. Deveraux, N. Roy, H.R. Stennicke, T. Van Arsdale, Q. Zhou, S.M. Srinivasula, E.S. Alnemri, G.S. Salvesen, J.C. Reed, IAPs block apoptotic events induced by caspase- 8 and cytochrome c by direct inhibition of distinct caspases, Embo J, 17 (1998) 2215-2223.

[76] Y. Suzuki, Y. Nakabayashi, R. Takahashi, Ubiquitin-protein ligase activity of X-linked inhibitor of apoptosis protein promotes proteasomal degradation of caspase- 3 and enhances its anti-apoptotic effect in Fas-induced cell death, Proc Natl Acad Sci U S A, 98 (2001) 8662-8667.

[77] C. Du, M. Fang, Y. Li, L. Li, X. Wang, Smac, a mitochondrial protein that promotes cytochrome cdependent caspase activation by eliminating IAP inhibition, Cell, 102 (2000) 33-42.

[78] X.M. Sun, S.B. Bratton, M. Butterworth, M. MacFarlane, G.M. Cohen, Bcl-2 and Bcl-xL inhibit CD95-mediated apoptosis by preventing mitochondrial release of Smac/DIABLO and subsequent inactivation of X-linked inhibitor-of-apoptosis protein, J Biol Chem, 277 (2002) 11345-11351.

[79] M. Beneteau, M. Pizon, B. Chaigne-Delalande, S. Daburon, P. Moreau, F. De Giorgi, F. Ichas, A. Rebillard, M.T. Dimanche-Boitrel, J.L. Taupin, J.F. Moreau, P. Legembre, Localization of Fas/CD95 into the lipid rafts on down-modulation of the phosphatidylinositol 3-kinase signaling pathway, Mol Cancer Res, 6 (2008) 604-613.

[80] J.W. Peacock, J. Palmer, D. Fink, S. Ip, E.M. Pietras, A.L. Mui, S.W. Chung, M.E. Gleave, M.E. Cox, R. Parsons, M.E. Peter, C.J. Ong, PTEN loss promotes mitochondrially dependent type II Fas-induced apoptosis via PEA-15, Mol Cell Biol, 29 (2009) 1222-1234.

[81] A.S. Varadhachary, M. Edidin, A.M. Hanlon, M.E. Peter, P.H. Krammer, P. Salgame, Phosphatidylinositol 3'-kinase blocks CD95 aggregation and caspase-8 cleavage at the death-inducing signaling complex by modulating lateral diffusion of CD95, J Immunol, 166 (2001) 6564-6569.

[82] M. Pizon, H. Rampanarivo, S. Tauzin, B. Chaigne-Delalande, S. Daburon, M. Castroviejo, P. Moreau, J.F. Moreau, P. Legembre, Actin-independent exclusion of CD95 by PI3K/AKT signalling: implications for apoptosis, Eur J Immunol, 41 (2011) 2368-2378.

[83] H. Renganathan, H. Vaidyanathan, A. Knapinska, J.W. Ramos, Phosphorylation of PEA-15 switches its binding specificity from ERK/MAPK to FADD, Biochem J, 390 (2005) 729-735.

[84] A. Trencia, A. Perfetti, A. Cassese, G. Vigliotta, C. Miele, F. Oriente, S. Santopietro, F. Giacco, G. Condorelli, P. Formisano, F. Beguinot, Protein kinase B/Akt binds and phosphorylates PED/PEA-15, stabilizing its antiapoptotic action, Mol Cell Biol, 23 (2003) 4511-4521.

[85] A. Strasser, A.W. Harris, D.C. Huang, P.H. Krammer, S. Cory, Bcl-2 and Fas/APO-1 regulate distinct pathways to lymphocyte apoptosis, Embo J, 14 (1995) 6136-6147.

[86] V. Lacronique, A. Mignon, M. Fabre, B. Viollet, N. Rouquet, T. Molina, A. Porteu, A. Henrion, D. Bouscary, P. Varlet, V. Joulin, A. Kahn, Bcl-2 protects from lethal hepatic apoptosis induced by an anti-Fas antibody in mice, Nat Med, 2 (1996) 80-86.

[87] I. Rodriguez, K. Matsuura, K. Khatib, J.C. Reed, S. Nagata, P. Vassalli, A bcl-2 transgene expressed in hepatocytes protects mice from fulminant liver destruction but not from rapid death induced by anti-Fas antibody injection, J Exp Med, 183 (1996) 1031-1036.

[88] J. Drappa, A.K. Vaishnaw, K.E. Sullivan, J.L. Chu, K.B. Elkon, Fas gene mutations in the CanaleSmith syndrome, an inherited lymphoproliferative disorder associated with autoimmunity, N Engl J Med, 335 (1996) 1643-1649.

[89] G.H. Fisher, F.J. Rosenberg, S.E. Straus, J.K. Dale, L.A. Middleton, A.Y. Lin, W. Strober, M.J. Lenardo, J.M. Puck, Dominant interfering Fas gene mutations impair apoptosis in a human autoimmune lymphoproliferative syndrome, Cell, 81 (1995) 935-946. 
[90] F. Rieux-Laucat, F. Le Deist, C. Hivroz, I.A. Roberts, K.M. Debatin, A. Fischer, J.P. de Villartay, Mutations in Fas associated with human lymphoproliferative syndrome and autoimmunity, Science, 268 (1995) 1347-1349.

[91] V.C. Canale, C.H. Smith, Chronic lymphadenopathy simulating malignant lymphoma, J Pediatr, 70 (1967) 891-899.

[92] F. Rieux-Laucat, S. Blachere, S. Danielan, J.P. De Villartay, M. Oleastro, E. Solary, B. BaderMeunier, P. Arkwright, C. Pondare, F. Bernaudin, H. Chapel, S. Nielsen, M. Berrah, A. Fischer, F. Le Deist, Lymphoproliferative syndrome with autoimmunity: A possible genetic basis for dominant expression of the clinical manifestations, Blood, 94 (1999) 2575-2582.

[93] S.E. Straus, E.S. Jaffe, J.M. Puck, J.K. Dale, K.B. Elkon, A. Rosen-Wolff, A.M. Peters, M.C. Sneller, C.W. Hallahan, J. Wang, R.E. Fischer, C.M. Jackson, A.Y. Lin, C. Baumler, E. Siegert, A. Marx, A.K. Vaishnaw, T. Grodzicky, T.A. Fleisher, M.J. Lenardo, The development of lymphomas in families with autoimmune lymphoproliferative syndrome with germline Fas mutations and defective lymphocyte apoptosis, Blood, 98 (2001) 194-200.

[94] A. Hennino, M. Berard, P.H. Krammer, T. Defrance, FLICE-inhibitory protein is a key regulator of germinal center B cell apoptosis, J Exp Med, 193 (2001) 447-458.

[95] M. Montesinos-Rongen, D. Van Roost, C. Schaller, O.D. Wiestler, M. Deckert, Primary diffuse large B-cell lymphomas of the central nervous system are targeted by aberrant somatic hypermutation, Blood, 103 (2004) 1869-1875.

[96] M. Muschen, K. Rajewsky, M. Kronke, R. Kuppers, The origin of CD95-gene mutations in B-cell lymphoma, Trends Immunol, 23 (2002) 75-80.

[97] M.E. Peter, P. Legembre, B.C. Barnhart, Does CD95 have tumor promoting activities?, Biochim Biophys Acta, 1755 (2005) 25-36.

[98] P. Legembre, B.C. Barnhart, M.E. Peter, The relevance of NF-kappaB for CD95 signaling in tumor cells, Cell Cycle, 3 (2004) 1235-1239.

[99] P. Legembre, B.C. Barnhart, L. Zheng, S. Vijayan, S.E. Straus, J. Puck, J.K. Dale, M. Lenardo, M.E. Peter, Induction of apoptosis and activation of NF-kappaB by CD95 require different signalling thresholds, EMBO Rep, 5 (2004) 1084-1089.

[100] B.C. Barnhart, P. Legembre, E. Pietras, C. Bubici, G. Franzoso, M.E. Peter, CD95 ligand induces motility and invasiveness of apoptosis-resistant tumor cells, Embo J, 23 (2004) 3175-3185.

[101] M. Kimura, A. Matsuzawa, Autoimmunity in mice bearing Iprcg: a novel mutant gene, Int Rev Immunol, 11 (1994) 193-210.

[102] T. Takahashi, M. Tanaka, C.I. Brannan, N.A. Jenkins, N.G. Copeland, T. Suda, S. Nagata, Generalized lymphoproliferative disease in mice, caused by a point mutation in the Fas ligand, Cell, 76 (1994) 969-976.

[103] R. Watanabe-Fukunaga, C.I. Brannan, N.G. Copeland, N.A. Jenkins, S. Nagata, Lymphoproliferation disorder in mice explained by defects in Fas antigen that mediates apoptosis, Nature, 356 (1992) 314-317.

[104] M. Adachi, R. Watanabe-Fukunaga, S. Nagata, Aberrant transcription caused by the insertion of an early transposable element in an intron of the Fas antigen gene of Ipr mice, Proc Natl Acad Sci U S A, 90 (1993) 1756-1760.

[105] J.L. Chu, J. Drappa, A. Parnassa, K.B. Elkon, The defect in Fas mRNA expression in MRL/Ipr mice is associated with insertion of the retrotransposon, ETn, J Exp Med, 178 (1993) 723-730.

[106] A. Matsuzawa, T. Moriyama, T. Kaneko, M. Tanaka, M. Kimura, H. Ikeda, T. Katagiri, A new allele of the Ipr locus, Iprcg, that complements the gld gene in induction of lymphadenopathy in the mouse, J Exp Med, 171 (1990) 519-531.

[107] A. Strasser, P.J. Jost, S. Nagata, The many roles of FAS receptor signaling in the immune system, Immunity, 30 (2009) 180-192.

[108] F. Heinzelmann, V. Jendrossek, K. Lauber, K. Nowak, T. Eldh, R. Boras, R. Handrick, M. Henkel, C. Martin, S. Uhlig, D. Kohler, H.K. Eltzschig, M. Wehrmann, W. Budach, C. Belka, Irradiation-induced pneumonitis mediated by the CD95/CD95-ligand system, J Natl Cancer Inst, 98 (2006) 1248-1251. 
[109] S. Kobayashi, T. Hirano, M. Kakinuma, T. Uede, Transcriptional repression and differential splicing of Fas mRNA by early transposon (ETn) insertion in autoimmune Ipr mice, Biochem Biophys Res Commun, 191 (1993) 617-624.

[110] J. Wu, T. Zhou, J. He, J.D. Mountz, Autoimmune disease in mice due to integration of an endogenous retrovirus in an apoptosis gene, J Exp Med, 178 (1993) 461-468.

[111] D.A. Martin, L. Zheng, R.M. Siegel, B. Huang, G.H. Fisher, J. Wang, C.E. Jackson, J.M. Puck, J. Dale, S.E. Straus, M.E. Peter, P.H. Krammer, S. Fesik, M.J. Lenardo, Defective CD95/APO-1/Fas signal complex formation in the human autoimmune lymphoproliferative syndrome, type la, Proc Natl Acad Sci U S A, 96 (1999) 4552-4557.

[112] J.R. Orlinick, K.B. Elkon, M.V. Chao, Separate domains of the human fas ligand dictate selfassociation and receptor binding, J Biol Chem, 272 (1997) 32221-32229.

[113] J.L. Chu, P. Ramos, A. Rosendorff, J. Nikolic-Zugic, E. Lacy, A. Matsuzawa, K.B. Elkon, Massive upregulation of the Fas ligand in Ipr and gld mice: implications for Fas regulation and the graftversus-host disease-like wasting syndrome, J Exp Med, 181 (1995) 393-398.

[114] A. Hadji, P. Ceppi, A.E. Murmann, S. Brockway, A. Pattanayak, B. Bhinder, A. Hau, S. De Chant, V. Parimi, P. Kolesza, J. Richards, N. Chandel, H. Djaballah, M.E. Peter, Death Induced by CD95 or CD95 Ligand Elimination, Cell reports, (2014).

[115] I.N. Lavrik, A. Golks, D. Riess, M. Bentele, R. Eils, P.H. Krammer, Analysis of CD95 threshold signaling: triggering of CD95 (FAS/APO-1) at low concentrations primarily results in survival signaling, J Biol Chem, 282 (2007) 13664-13671.

[116] S. Kleber, I. Sancho-Martinez, B. Wiestler, A. Beisel, C. Gieffers, O. Hill, M. Thiemann, W. Mueller, J. Sykora, A. Kuhn, N. SchregImann, E. Letellier, C. Zuliani, S. Klussmann, M. Teodorczyk, H.J. Grone, T.M. Ganten, H. Sultmann, J. Tuttenberg, A. von Deimling, A. Regnier-Vigouroux, C. HeroldMende, A. Martin-Villalba, Yes and PI3K bind CD95 to signal invasion of glioblastoma, Cancer Cell, 13 (2008) 235-248.

[117] M. Malleter, S. Tauzin, A. Bessede, R. Castellano, A. Goubard, F. Godey, J. Leveque, P. Jezequel, L. Campion, M. Campone, T. Ducret, G. Macgrogan, L. Debure, Y. Collette, P. Vacher, P. Legembre, CD95L cell surface cleavage triggers a prometastatic signaling pathway in triple-negative breast cancer, Cancer Res, 73 (2013) 6711-6721.

[118] H. Grassme, A. Jekle, A. Riehle, H. Schwarz, J. Berger, K. Sandhoff, R. Kolesnick, E. Gulbins, CD95 signaling via ceramide-rich membrane rafts, J Biol Chem, 276 (2001) 20589-20596.

[119] J.R. Muppidi, R.M. Siegel, Ligand-independent redistribution of Fas (CD95) into lipid rafts mediates clonotypic T cell death, Nat Immunol, 5 (2004) 182-189.

[120] A.J. Stel, B. Ten Cate, S. Jacobs, J.W. Kok, D.C. Spierings, M. Dondorff, W. Helfrich, H.C. KluinNelemans, L.F. de Leij, S. Withoff, B.J. Kroesen, Fas receptor clustering and involvement of the death receptor pathway in rituximab-mediated apoptosis with concomitant sensitization of lymphoma $B$ cells to fas-induced apoptosis, J Immunol, 178 (2007) 2287-2295.

[121] D. Delmas, C. Rebe, S. Lacour, R. Filomenko, A. Athias, P. Gambert, M. Cherkaoui-Malki, B. Jannin, L. Dubrez-Daloz, N. Latruffe, E. Solary, Resveratrol-induced apoptosis is associated with Fas redistribution in the rafts and the formation of a death-inducing signaling complex in colon cancer cells, J Biol Chem, 278 (2003) 41482-41490.

[122] D. Delmas, C. Rebe, O. Micheau, A. Athias, P. Gambert, S. Grazide, G. Laurent, N. Latruffe, E. Solary, Redistribution of CD95, DR4 and DR5 in rafts accounts for the synergistic toxicity of resveratrol and death receptor ligands in colon carcinoma cells, Oncogene, 23 (2004) 8979-8986.

[123] C. Gajate, E. Del Canto-Janez, A.U. Acuna, F. Amat-Guerri, E. Geijo, A.M. Santos-Beneit, R.J. Veldman, F. Mollinedo, Intracellular triggering of Fas aggregation and recruitment of apoptotic molecules into Fas-enriched rafts in selective tumor cell apoptosis, J Exp Med, 200 (2004) 353-365.

[124] C. Gajate, F. Mollinedo, Edelfosine and perifosine induce selective apoptosis in multiple myeloma by recruitment of death receptors and downstream signaling molecules into lipid rafts, Blood, 109 (2007) 711-719. 
[125] C. Gajate, F. Mollinedo, Cytoskeleton-mediated death receptor and ligand concentration in lipid rafts forms apoptosis-promoting clusters in cancer chemotherapy, J Biol Chem, 280 (2005) 1164111647.

[126] S. Lacour, A. Hammann, S. Grazide, D. Lagadic-Gossmann, A. Athias, O. Sergent, G. Laurent, P. Gambert, E. Solary, M.T. Dimanche-Boitrel, Cisplatin-induced CD95 redistribution into membrane lipid rafts of HT29 human colon cancer cells, Cancer Res, 64 (2004) 3593-3598.

[127] V. Anathy, S.W. Aesif, A.S. Guala, M. Havermans, N.L. Reynaert, Y.S. Ho, R.C. Budd, Y.M. Janssen-Heininger, Redox amplification of apoptosis by caspase-dependent cleavage of glutaredoxin 1 and S-glutathionylation of Fas, J Cell Biol, 184 (2009) 241-252.

[128] A. Oehm, I. Behrmann, W. Falk, M. Pawlita, G. Maier, C. Klas, M. Li-Weber, S. Richards, J. Dhein, B.C. Trauth, et al., Purification and molecular cloning of the APO-1 cell surface antigen, a member of the tumor necrosis factor/nerve growth factor receptor superfamily. Sequence identity with the Fas antigen, The Journal of biological chemistry, 267 (1992) 10709-10715.

[129] H. Grassme, A. Cremesti, R. Kolesnick, E. Gulbins, Ceramide-mediated clustering is required for CD95-DISC formation, Oncogene, 22 (2003) 5457-5470.

[130] C.A. Chen, T.Y. Wang, S. Varadharaj, L.A. Reyes, C. Hemann, M.A. Talukder, Y.R. Chen, L.J. Druhan, J.L. Zweier, S-glutathionylation uncouples eNOS and regulates its cellular and vascular function, Nature, 468 (2010) 1115-1118.

[131] L. Leon-Bollotte, S. Subramaniam, O. Cauvard, S. Plenchette-Colas, C. Paul, C. Godard, A. Martinez-Ruiz, P. Legembre, J.F. Jeannin, A. Bettaieb, S-nitrosylation of the death receptor fas promotes fas ligand-mediated apoptosis in cancer cells, Gastroenterology, 140 (2011) 2009-2018, 2018 e2001-2004.

[132] K. Chakrabandhu, Z. Herincs, S. Huault, B. Dost, L. Peng, F. Conchonaud, D. Marguet, H.T. He, A.O. Hueber, Palmitoylation is required for efficient Fas cell death signaling, Embo J, 26 (2007) 209220.

[133] C. Feig, V. Tchikov, S. Schutze, M.E. Peter, Palmitoylation of CD95 facilitates formation of SDSstable receptor aggregates that initiate apoptosis signaling, Embo J, 26 (2007) 221-231.

[134] G. Gradl, P. Grandison, E. Lindridge, Y. Wang, J. Watson, F. Rudert, The CD95 (Fas/APO-1) receptor is phosphorylated in vitro and in vivo and constitutively associates with several cellular proteins, Apoptosis, 1 (1996) 131-140.

[135] I. Daigle, S. Yousefi, M. Colonna, D.R. Green, H.U. Simon, Death receptors bind SHP-1 and block cytokine-induced anti-apoptotic signaling in neutrophils, Nat Med, 8 (2002) 61-67.

[136] X. Su, T. Zhou, Z. Wang, P. Yang, R.S. Jope, J.D. Mountz, Defective expression of hematopoietic cell protein tyrosine phosphatase (HCP) in lymphoid cells blocks Fas-mediated apoptosis, Immunity, 2 (1995) 353-362.

[137] H. Ohno, J. Stewart, M.C. Fournier, H. Bosshart, I. Rhee, S. Miyatake, T. Saito, A. Gallusser, T. Kirchhausen, J.S. Bonifacino, Interaction of tyrosine-based sorting signals with clathrin-associated proteins, Science, 269 (1995) 1872-1875.

[138] K.H. Lee, C. Feig, V. Tchikov, R. Schickel, C. Hallas, S. Schutze, M.E. Peter, A.C. Chan, The role of receptor internalization in CD95 signaling, Embo J, 25 (2006) 1009-1023.

[139] E.A. Atkinson, H. Ostergaard, K. Kane, M.J. Pinkoski, A. Caputo, M.W. Olszowy, R.C. Bleackley, A physical interaction between the cell death protein Fas and the tyrosine kinase p59fynT, J Biol Chem, 271 (1996) 5968-5971.

[140] J. Wang, T. Koizumi, T. Watanabe, Altered antigen receptor signaling and impaired Fasmediated apoptosis of B cells in Lyn-deficient mice, J Exp Med, 184 (1996) 831-838.

[141] N. Khadra, L. Bresson-Bepoldin, A. Penna, B. Chaigne-Delalande, B. Segui, T. Levade, A.M. Vacher, J. Reiffers, T. Ducret, J.F. Moreau, M.D. Cahalan, P. Vacher, P. Legembre, CD95 triggers Orai1mediated localized $\mathrm{Ca} 2+$ entry, regulates recruitment of protein kinase $\mathrm{C}$ (PKC) beta2, and prevents death-inducing signaling complex formation, Proc Natl Acad Sci U S A, 108 (2011) 19072-19077.

[142] A. Penna, N. Khadra, S. Tauzin, P. Vacher, P. Legembre, The CD95 signaling pathway: To not die and fly, Communicative \& integrative biology, 5 (2012) 190-192. 
[143] B.Z. Stanger, P. Leder, T.H. Lee, E. Kim, B. Seed, RIP: a novel protein containing a death domain that interacts with Fas/APO-1 (CD95) in yeast and causes cell death, Cell, 81 (1995) 513-523.

[144] A. Degterev, Z. Huang, M. Boyce, Y. Li, P. Jagtap, N. Mizushima, G.D. Cuny, T.J. Mitchison, M.A. Moskowitz, J. Yuan, Chemical inhibitor of nonapoptotic cell death with therapeutic potential for ischemic brain injury, Nat Chem Biol, 1 (2005) 112-119.

[145] A. Degterev, J. Hitomi, M. Germscheid, I.L. Ch'en, O. Korkina, X. Teng, D. Abbott, G.D. Cuny, C. Yuan, G. Wagner, S.M. Hedrick, S.A. Gerber, A. Lugovskoy, J. Yuan, Identification of RIP1 kinase as a specific cellular target of necrostatins, Nat Chem Biol, 4 (2008) 313-321.

[146] E.W. Lee, J. Seo, M. Jeong, S. Lee, J. Song, The roles of FADD in extrinsic apoptosis and necroptosis, BMB reports, 45 (2012) 496-508.

[147] Y. Lin, A. Devin, Y. Rodriguez, Z.G. Liu, Cleavage of the death domain kinase RIP by caspase-8 prompts TNF-induced apoptosis, Genes Dev, 13 (1999) 2514-2526.

[148] S. Feng, Y. Yang, Y. Mei, L. Ma, D.E. Zhu, N. Hoti, M. Castanares, M. Wu, Cleavage of RIP3 inactivates its caspase-independent apoptosis pathway by removal of kinase domain, Cell Signal, 19 (2007) 2056-2067.

[149] M.A. O'Donnell, E. Perez-Jimenez, A. Oberst, A. Ng, R. Massoumi, R. Xavier, D.R. Green, A.T. Ting, Caspase 8 inhibits programmed necrosis by processing CYLD, Nat Cell Biol, 13 (2011) 1437-1442. [150] M.E. Peter, Programmed cell death: Apoptosis meets necrosis, Nature, 471 (2011) 310-312.

[151] A.H. Montel, M.R. Bochan, J.A. Hobbs, D.H. Lynch, Z. Brahmi, Fas involvement in cytotoxicity mediated by human NK cells, Cell Immunol, 166 (1995) 236-246.

[152] P. Saas, P.R. Walker, M. Hahne, A.L. Quiquerez, V. Schnuriger, G. Perrin, L. French, E.G. Van Meir, N. de Tribolet, J. Tschopp, P.Y. Dietrich, Fas ligand expression by astrocytoma in vivo: maintaining immune privilege in the brain?, J Clin Invest, 99 (1997) 1173-1178.

[153] P.M. Stuart, T.S. Griffith, N. Usui, J. Pepose, X. Yu, T.A. Ferguson, CD95 ligand (FasL)-induced apoptosis is necessary for corneal allograft survival, J Clin Invest, 99 (1997) 396-402.

[154] M. Hahne, D. Rimoldi, M. Schroter, P. Romero, M. Schreier, L.E. French, P. Schneider, T. Bornand, A. Fontana, D. Lienard, J. Cerottini, J. Tschopp, Melanoma cell expression of Fas(Apo1/CD95) ligand: implications for tumor immune escape, Science, 274 (1996) 1363-1366.

[155] J. O'Connell, G.C. O'Sullivan, J.K. Collins, F. Shanahan, The Fas counterattack: Fas-mediated T cell killing by colon cancer cells expressing Fas ligand, J Exp Med, 184 (1996) 1075-1082.

[156] J. Allison, H.M. Georgiou, A. Strasser, D.L. Vaux, Transgenic expression of CD95 ligand on islet beta cells induces a granulocytic infiltration but does not confer immune privilege upon islet allografts, Proc Natl Acad Sci U S A, 94 (1997) 3943-3947.

[157] S.M. Kang, D.B. Schneider, Z. Lin, D. Hanahan, D.A. Dichek, P.G. Stock, S. Baekkeskov, Fas ligand expression in islets of Langerhans does not confer immune privilege and instead targets them for rapid destruction, Nat Med, 3 (1997) 738-743.

[158] J.J. Chen, Y. Sun, G.J. Nabel, Regulation of the proinflammatory effects of Fas ligand (CD95L), Science, 282 (1998) 1714-1717.

[159] J.D. Bui, R.D. Schreiber, Cancer immunosurveillance, immunoediting and inflammation: independent or interdependent processes?, Curr Opin Immunol, 19 (2007) 203-208.

[160] M. Beneteau, S. Daburon, J.F. Moreau, J.L. Taupin, P. Legembre, Dominant-negative Fas mutation is reversed by down-expression of c-FLIP, Cancer Res, 67 (2007) 108-115.

[161] L. Chen, S.M. Park, A.V. Tumanov, A. Hau, K. Sawada, C. Feig, J.R. Turner, Y.X. Fu, I.L. Romero, E. Lengyel, M.E. Peter, CD95 promotes tumour growth, Nature, 465 (2010) 492-496.

[162] H. Matsuno, K. Yudoh, Y. Watanabe, F. Nakazawa, H. Aono, T. Kimura, Stromelysin-1 (MMP-3) in synovial fluid of patients with rheumatoid arthritis has potential to cleave membrane bound Fas ligand, J Rheumatol, 28 (2001) 22-28.

[163] T. Vargo-Gogola, H.C. Crawford, B. Fingleton, L.M. Matrisian, Identification of novel matrix metalloproteinase-7 (matrilysin) cleavage sites in murine and human Fas ligand, Arch Biochem Biophys, 408 (2002) 155-161.

[164] M. Kiaei, K. Kipiani, N.Y. Calingasan, E. Wille, J. Chen, B. Heissig, S. Rafii, S. Lorenzl, M.F. Beal, Matrix metalloproteinase-9 regulates TNF-alpha and FasL expression in neuronal, glial cells and its 
absence extends life in a transgenic mouse model of amyotrophic lateral sclerosis, Exp Neurol, 205 (2007) 74-81.

[165] V. Kirkin, N. Cahuzac, F. Guardiola-Serrano, S. Huault, K. Luckerath, E. Friedmann, N. Novac, W.S. Wels, B. Martoglio, A.O. Hueber, M. Zornig, The Fas ligand intracellular domain is released by ADAM10 and SPPL2a cleavage in T-cells, Cell Death Differ, 14 (2007) 1678-1687.

[166] M. Schulte, K. Reiss, M. Lettau, T. Maretzky, A. Ludwig, D. Hartmann, B. de Strooper, O. Janssen, P. Saftig, ADAM10 regulates FasL cell surface expression and modulates FasL-induced cytotoxicity and activation-induced cell death, Cell Death Differ, 14 (2007) 1040-1049.

[167] N. Holler, A. Tardivel, M. Kovacsovics-Bankowski, S. Hertig, O. Gaide, F. Martinon, A. Tinel, D. Deperthes, S. Calderara, T. Schulthess, J. Engel, P. Schneider, J. Tschopp, Two adjacent trimeric Fas ligands are required for Fas signaling and formation of a death-inducing signaling complex, Mol Cell Biol, 23 (2003) 1428-1440.

[168] P. Schneider, N. Holler, J.L. Bodmer, M. Hahne, K. Frei, A. Fontana, J. Tschopp, Conversion of membrane-bound Fas(CD95) ligand to its soluble form is associated with downregulation of its proapoptotic activity and loss of liver toxicity, J Exp Med, 187 (1998) 1205-1213.

[169] T. Suda, H. Hashimoto, M. Tanaka, T. Ochi, S. Nagata, Membrane Fas ligand kills human peripheral blood T lymphocytes, and soluble Fas ligand blocks the killing, J Exp Med, 186 (1997) 20452050.

[170] S. Cursi, A. Rufini, V. Stagni, I. Condo, V. Matafora, A. Bachi, A.P. Bonifazi, L. Coppola, G. SupertiFurga, R. Testi, D. Barila, Src kinase phosphorylates Caspase-8 on Tyr380: a novel mechanism of apoptosis suppression, EMBO J, 25 (2006) 1895-1905.

[171] J. Senft, B. Helfer, S.M. Frisch, Caspase-8 interacts with the p85 subunit of phosphatidylinositol 3-kinase to regulate cell adhesion and motility, Cancer Res, 67 (2007) 11505-11509.

[172] E.J. Steller, I.H. Borel Rinkes, O. Kranenburg, How CD95 stimulates invasion, Cell Cycle, 10 (2011) 3857-3862.

[173] E.J. Steller, L. Ritsma, D.A. Raats, F.J. Hoogwater, B.L. Emmink, K.M. Govaert, J. Laoukili, I.H. Rinkes, J. van Rheenen, O. Kranenburg, The death receptor CD95 activates the cofilin pathway to stimulate tumour cell invasion, EMBO Rep, 12 (2011) 931-937.

[174] T.G. Bivona, H. Hieronymus, J. Parker, K. Chang, M. Taron, R. Rosell, P. Moonsamy, K. Dahlman, V.A. Miller, C. Costa, G. Hannon, C.L. Sawyers, FAS and NF-kappaB signalling modulate dependence of lung cancers on mutant EGFR, Nature, 471 (2011) 523-526.

[175] G. Bellone, C. Smirne, A. Carbone, K. Mareschi, L. Dughera, E.C. Farina, O. Alabiso, G. Valente, G. Emanuelli, U. Rodeck, Production and pro-apoptotic activity of soluble CD95 ligand in pancreatic carcinoma, Clinical cancer research, 6 (2000) 2448-2455.

[176] M. Malleter, S. Tauzin, A. Bessede, R. Castellano, A. Goubard, F. Godey, J. Leveque, P. Jezequel, L. Campion, M. Campone, T. Ducret, G. Macgrogan, L. Debure, Y. Collette, P. Vacher, P. Legembre, CD95L cell surface cleavage triggers a pro-metastatic signaling pathway in triple negative breast cancer, Cancer Res, (2013).

[177] M. Tanaka, T. Suda, K. Haze, N. Nakamura, K. Sato, F. Kimura, K. Motoyoshi, M. Mizuki, S. Tagawa, S. Ohga, K. Hatake, A.H. Drummond, S. Nagata, Fas ligand in human serum, Nat Med, 2 (1996) 317-322.

[178] H. Hashimoto, M. Tanaka, T. Suda, T. Tomita, K. Hayashida, E. Takeuchi, M. Kaneko, H. Takano, S. Nagata, T. Ochi, Soluble Fas ligand in the joints of patients with rheumatoid arthritis and osteoarthritis, Arthritis and rheumatism, 41 (1998) 657-662.

[179] H. Das, S. Imoto, T. Murayama, K. Kajimoto, T. Sugimoto, T. Isobe, T. Nakagawa, R. Nishimura, T. Koizumi, Levels of soluble FasL and FasL gene expression during the development of graft-versushost disease in DLT-treated patients, British journal of haematology, 104 (1999) 795-800.

[180] Y. Kanda, Y. Tanaka, K. Shirakawa, T. Yatomi, N. Nakamura, M. Kami, T. Saito, K. Izutsu, T. Asai, K. Yuji, S. Ogawa, H. Honda, K. Mitani, S. Chiba, Y. Yazaki, H. Hirai, Increased soluble Fas-ligand in sera of bone marrow transplant recipients with acute graft-versus-host disease, Bone marrow transplantation, 22 (1998) 751-754. 
[181] A. Tomokuni, T. Otsuki, Y. Isozaki, S. Kita, H. Ueki, M. Kusaka, T. Kishimoto, A. Ueki, Serum levels of soluble Fas ligand in patients with silicosis, Clinical and experimental immunology, 118 (1999) 441-444.

[182] R. Herrero, O. Kajikawa, G. Matute-Bello, Y. Wang, N. Hagimoto, S. Mongovin, V. Wong, D.R. Park, N. Brot, J.W. Heinecke, H. Rosen, R.B. Goodman, X. Fu, T.R. Martin, The biological activity of FasL in human and mouse lungs is determined by the structure of its stalk region, The Journal of clinical investigation, 121 (2011) 1174-1190.

[183] R. Alonso, C. Mazzeo, M.C. Rodriguez, M. Marsh, A. Fraile-Ramos, V. Calvo, A. Avila-Flores, I. Merida, M. Izquierdo, Diacylglycerol kinase alpha regulates the formation and polarisation of mature multivesicular bodies involved in the secretion of Fas ligand-containing exosomes in T lymphocytes, Cell death and differentiation, 18 (2011) 1161-1173.

[184] N.R. Bianco, S.H. Kim, A.E. Morelli, P.D. Robbins, Modulation of the immune response using dendritic cell-derived exosomes, Methods Mol Biol, 380 (2007) 443-455.

[185] A.J. Abusamra, Z. Zhong, X. Zheng, M. Li, T.E. Ichim, J.L. Chin, W.P. Min, Tumor exosomes expressing Fas ligand mediate CD8+ T-cell apoptosis, Blood Cells Mol Dis, 35 (2005) 169-173.

[186] P. Schneider, J.L. Bodmer, N. Holler, C. Mattmann, P. Scuderi, A. Terskikh, M.C. Peitsch, J. Tschopp, Characterization of Fas (Apo-1, CD95)-Fas ligand interaction, J Biol Chem, 272 (1997) 1882718833. 


\section{Figure Legends}

Figure 1. CD95: mRNA to protein.

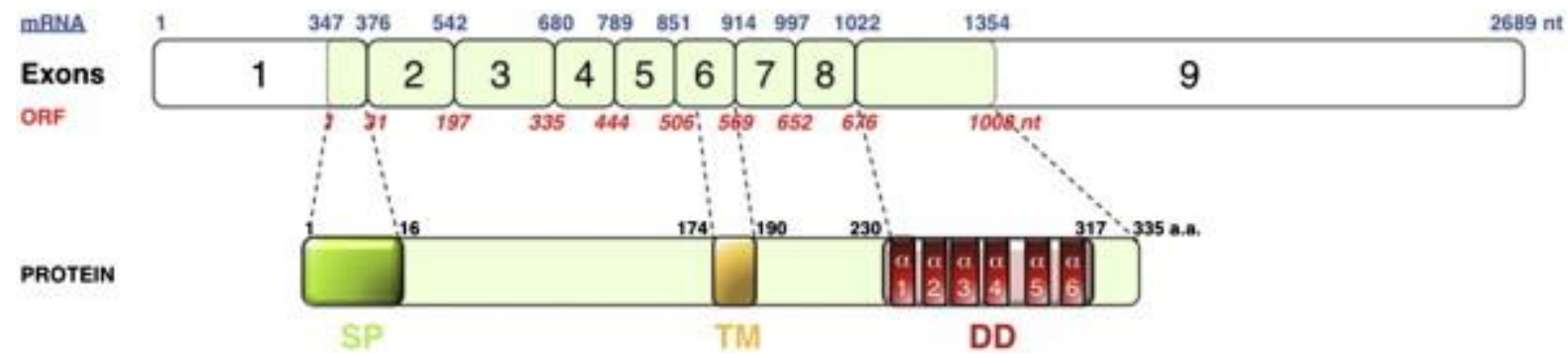

Upper panel: The CD95 mRNA consists of nine exons. The open reading frame (ORF) is indicated. Lower panel: Three main domains of the protein are depicted: signal peptide (SP), transmembrane domain (TM), and death domain (DD). DD is a protein module composed of a bundle of six alpha-helices

Figure 2. Type I / II cells.

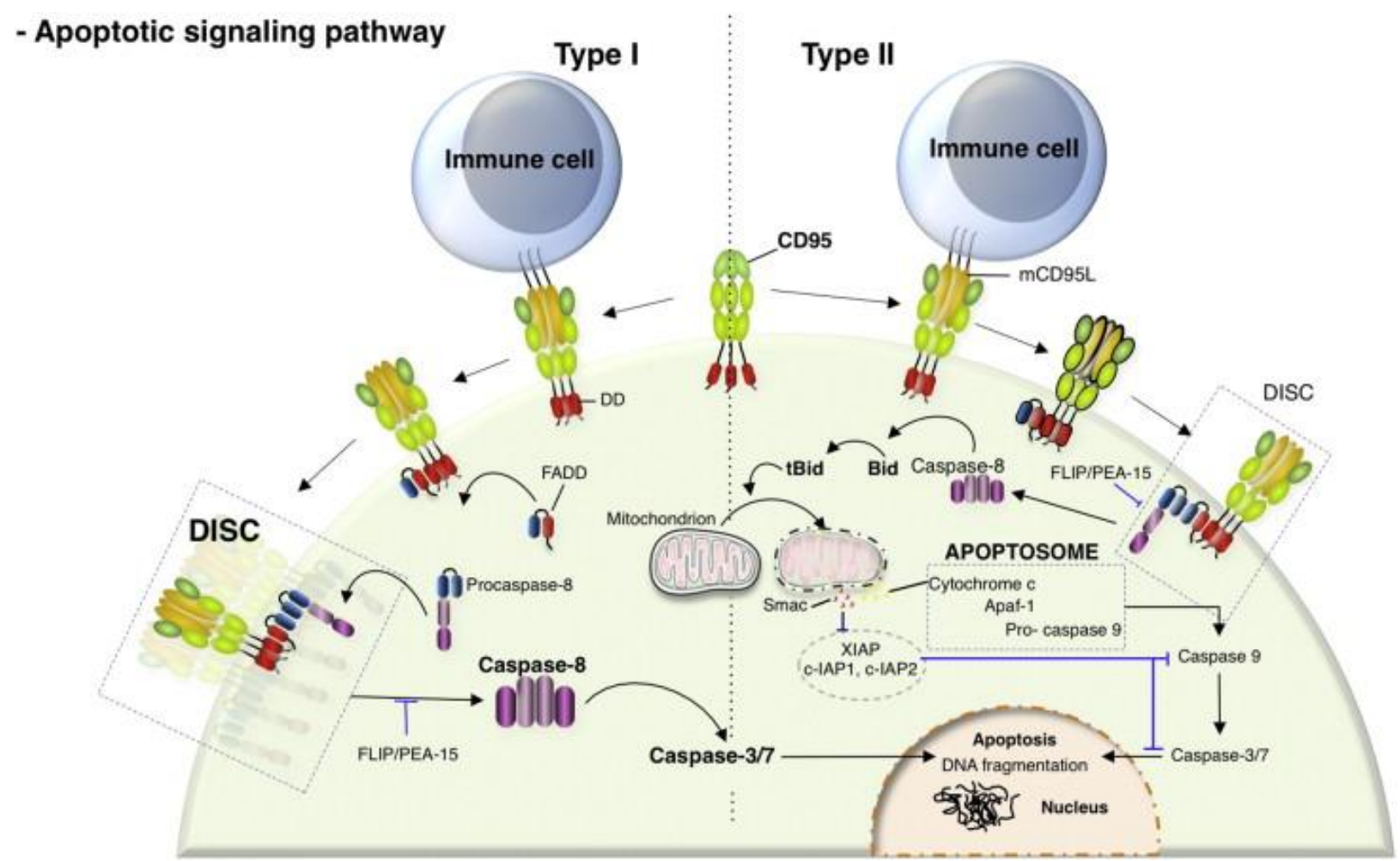


Binding of transmembrane CD95L to CD95 leads to formation of the DISC, which consists of FADD and procaspase-8. C-FLIP and PEA-15 bind to FADD, thereby preventing caspase-8 recruitment. At the level of the DISC, aggregation of procaspase- 8 promotes its auto-cleavage and activation. Cleaved caspase- 8 is then released to the cytosol, where it promotes the cascade of caspase activation leading to apoptosis. Type I cells are characterized by an efficient DISC formation, which releases sufficient caspase-8 to directly activate caspase-3. By contrast, type II cells form low levels of the DISC, and the resultant weak amount of released caspase- 8 activates the mitochondrion-dependent apoptotic pathway to amplify the death signal.

Figure 3. Distribution of somatic and germinal mutations within the CD95 protein sequence. 


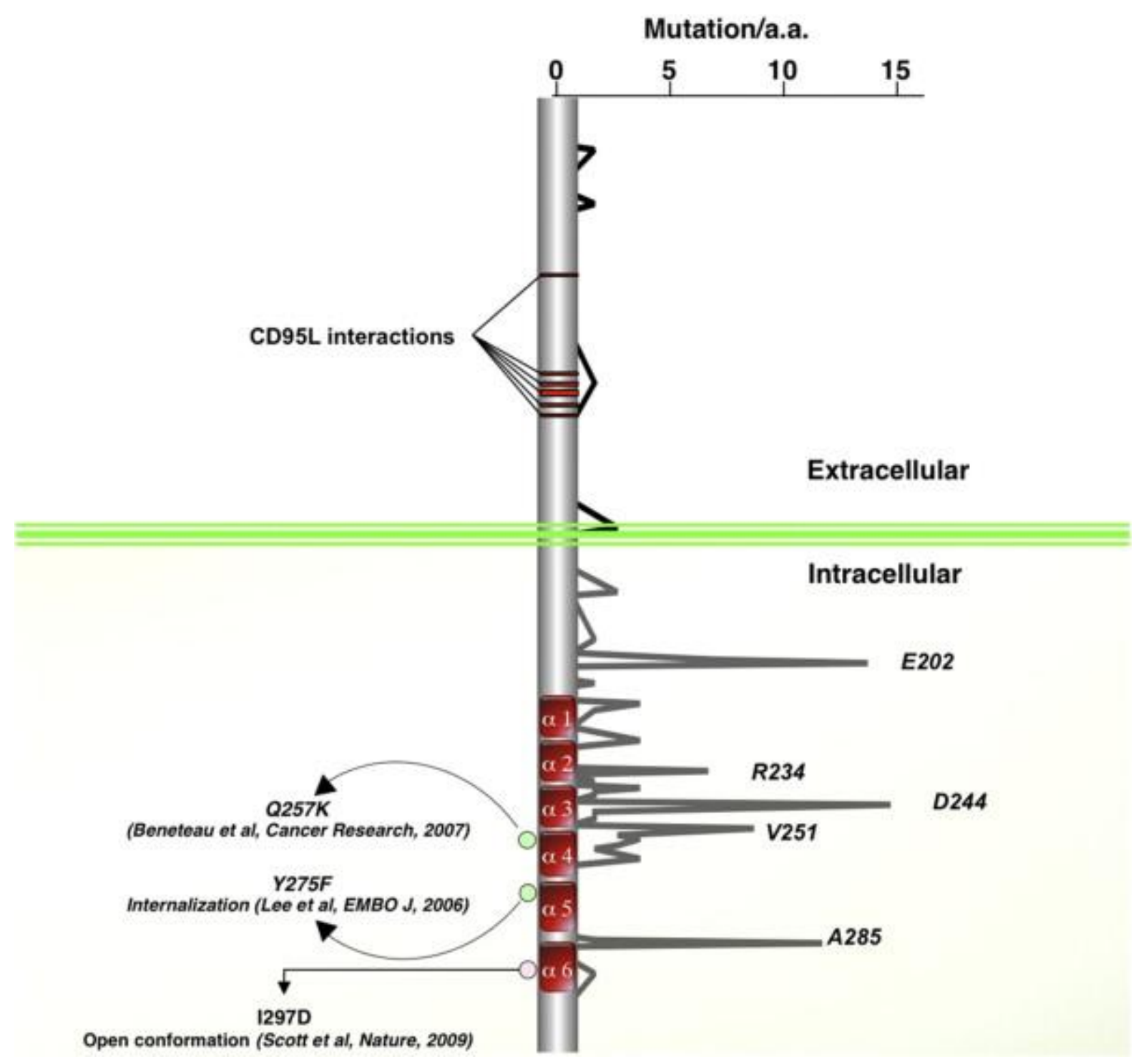

A comprehensive analysis of CD95 mutations is shown. Most of the mutations are distributed within the CD95-DD[51]. Whereas Q257K perturbs FADD binding, replacement of tyrosine at position 275 by phenylalanine prevents CD95 internalization without altering FADD recruitment [138], and I297D maintains the CD95-DD in an open conformation and promotes apoptosis[60]. 
Figure 4. CD95 triggers an unconventional PI3K signaling pathway.

- Pro-motility signaling pathway

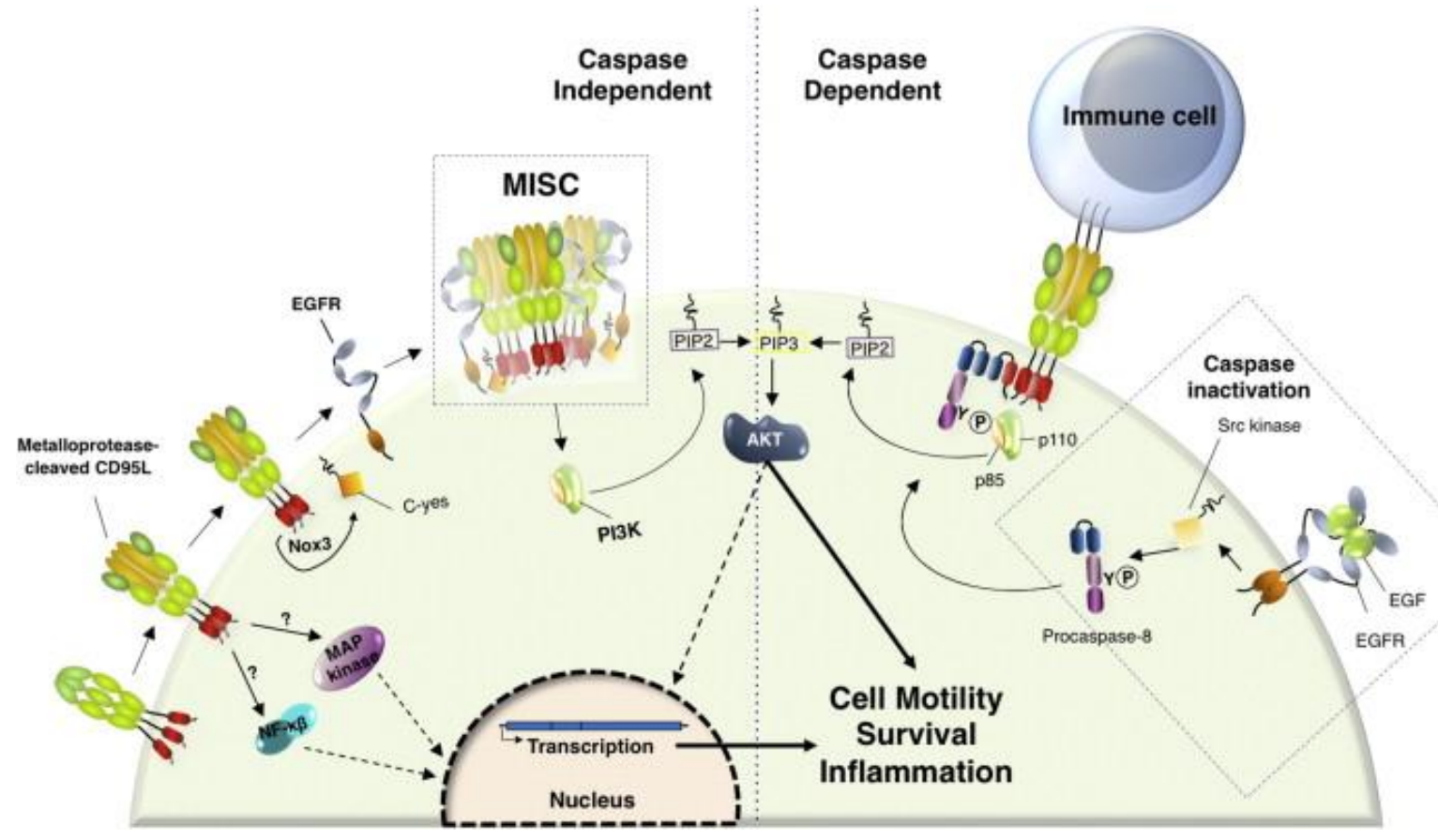

Left panel: In the presence of cl-CD95L, CD95 triggers MISC formation. The MISC complex is devoid of FADD and caspase-8, but instead recruits the src kinase c-yes, which implements the PI3K signaling pathway. CD95 engagement is also capable of activating $\mathrm{NF}-\kappa \mathrm{B}$ and MAPK through an as-yet-unknown mechanism. Right Panel: Procaspase-8 can be phosphorylated by the tyrosine kinase src upon EGFR stimulation. This post-translational modification not only blocks the catalytic activity of caspase- 8 , but also promotes the recruitment of the p85 subunit of PI3K. We surmise that caspase- 8 phosphorylation promotes the non-apoptotic signals induced by CD95. 
Figure 5. CD95L: metalloprotease cleavage sites and domains.

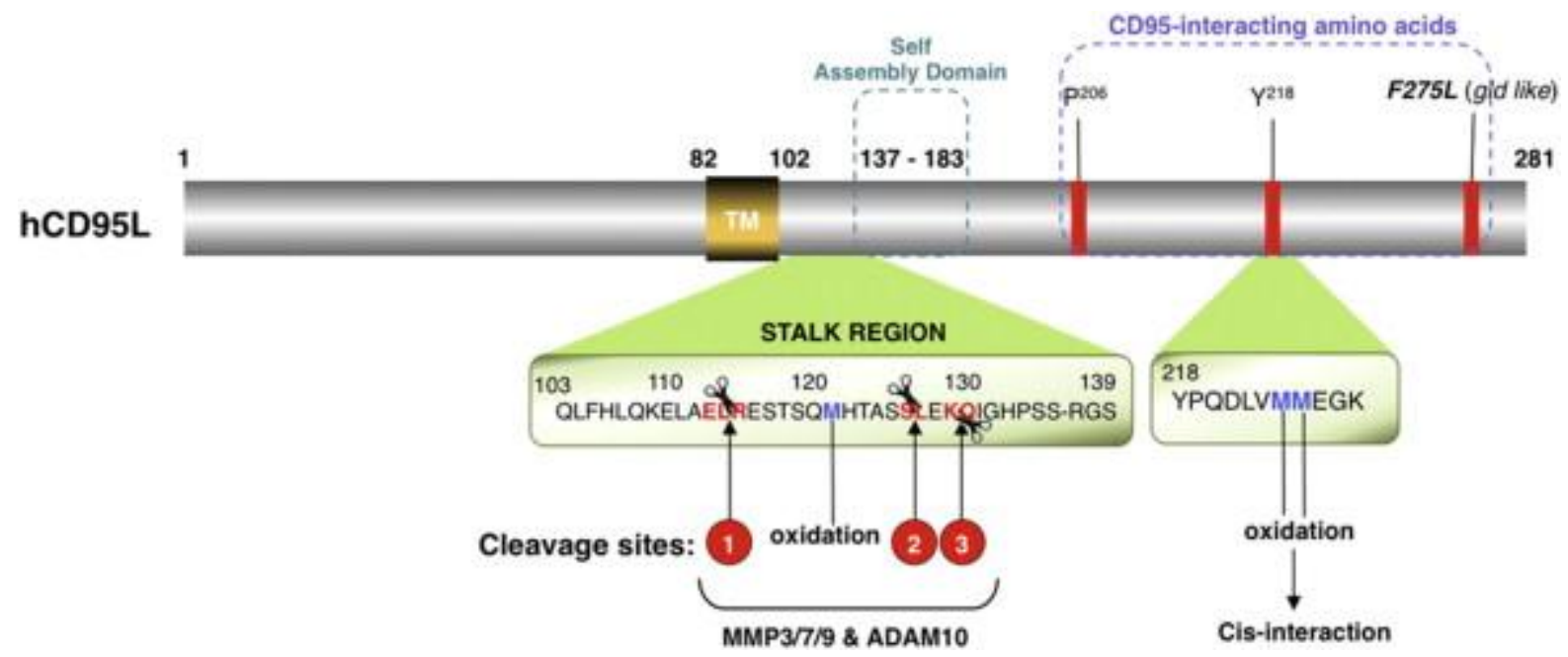

Schematic of the human CD95L protein. The juxtamembrane region, also called the stalk region, encompasses three different cleavage sites. Amino acids involved in its interaction with CD95 are indicated [186]. Oxidation of methionine residues in position 224 and 225 increases the aggregation level of the soluble ligand, whereas oxidation at methionine 121 prevents the processing of CD95L by metalloproteases [182]. TM: transmembrane domain. 